\title{
The role of the inflammatory microenvironment in thyroid carcinogenesis
}

\section{Lucas Leite Cunha, Marjory Alana Marcello and Laura Sterian Ward}

Laboratory of Cancer Molecular Genetics, Faculty of Medical Sciences, University of Campinas (FCM-Unicamp), Rua Tessália Vieira de Camargo 126, Barão Geraldo, Campinas, São Paulo, Brazil
Correspondence should be addressed to LS Ward

Email ward@fcm.unicamp.br

\begin{abstract}
Immune responses against thyroid carcinomas have long been demonstrated and associations between inflammatory microenvironment and thyroid carcinomas repeatedly reported. This scenario has prompted scientists throughout the world to unveil how the inflammatory microenvironment is established in thyroid tumors and what is its influence on the outcome of patients with thyroid carcinoma. Many studies have reported the role of evasion from the immune system in tumor progression and reinforced the weakness of the innate immune response toward thyroid cancer spread in advanced stages. Translational studies have provided evidence that an increased density of tumor-associated macrophages in poorly differentiated thyroid carcinoma (DTC) is associated with an aggressive phenotype at diagnosis and decreased cancer-related survival, whereas well-DTC microenvironment enriched with macrophages is correlated with improved disease-free survival. It is possible that these different results are related to different microenvironments. Several studies have provided evidence that patients whose tumors are not infiltrated by lymphocytes present a high recurrence rate, suggesting that the presence of lymphocytes in the tumor microenvironment may favor the prognosis of patients with thyroid carcinoma. However, the effect of lymphocytes and other immune cells on patient outcome seems to result from complex interactions between the tumor and immune system, and the molecular pattern of cytokines and chemokines helps to explain the involvement of the immune system in thyroid tumor progression. The inflammatory microenvironment may help to characterize aggressive tumors and to identify patients who would benefit from a more invasive approach, probably sparing the vast majority of patients with an indolent disease from unnecessary procedures.
\end{abstract}

\section{Key Words}

- thyroid carcinomas

- inflammatory microenvironment

- tumor-infiltrating lymphocytes

- tumor-associated macrophages

\section{Introduction}

Immune responses against differentiated thyroid carcinomas (DTCs) have long been demonstrated (Matsubayashi et al. 1995, Modi et al. 2003) and associations between inflammatory microenvironment and DTCs repeatedly reported (Yano et al. 2007, Muzza et al. 2010), evidenced by a mixture of lymphocytes and macrophages frequently found within and inside or surrounding primary thyroid tumors (Modi et al. 2003, French et al. 2010). These data support the hypothesis that immune responses may influence DTC progression

Published by Bioscientifica Ltd 
(Gupta et al. 2001, Yano et al. 2007, Muzza et al. 2010). In fact, pathologists have long recognized that some tumors are densely infiltrated by cells of both innate and adaptive arms of the immune system, thereby reflecting inflammatory conditions arising in non-neoplastic tissues. In addition, clinicians have long realized that local inflammatory responses (Matsubayashi et al. 1995, Gupta et al. 2001) and concurrent chronic lymphocytic thyroiditis (Cunha \& Ward 2011, Huang et al. 2011) may be associated with the prognostic profile of patients with DTC. All these observations from the bedside have prompted scientists throughout the world to unveil how the inflammatory microenvironment is established in thyroid tumors and what is its influence on the outcome of patients with DTC.

\section{Principles of thyroid carcinogenesis}

Although $\sim 50-67 \%$ of the population will eventually present a thyroid nodule during their lives (Mazzaferri 2006, Cronan 2008), the malignant transformation of follicular cells is much less common and thyroid cancers account for no more than $2 \%$ of all human cancers (Sipos \& Mazzaferri 2010). The vast majority of thyroid neoplasms are derived from follicular epithelial cells and can be classified as follows: DTCs, which can be divided into papillary thyroid cancer (PTC) and follicular thyroid cancer, poorly DTC (PDTC), and undifferentiated thyroid carcinomas or anaplastic thyroid cancer (ATC).

In 2011, Hanahan \& Weinberg (2011) stated that a cell acquires ten biological abilities to become a tumor and considered hallmarks of cancer the ability to sustain proliferative signaling, evade growth suppressors, avoid immune destruction, enable replicative immortality, promote inflammation, induce angiogenesis, activate invasion and metastasis, promote genome instability and mutation, resist cell death, and deregulate cellular energetics. Such abilities may appear for different reasons and can be instigated by diverse agents. In the case of thyroid carcinomas, risk factors may include ionizing radiations (Nikiforov 2010, Wartofsky 2010), chronic inflammatory conditions such as obesity (Zhao et al. 2012, Han et al. 2013), and ingestion of some nutrients such as iodine and others (Marcello et al. 2012). Individual genetically inherited profiles of susceptibility (Granja et al. 2004a,b, Bufalo et al. 2006, Guilhen et al. 2009, $\mathrm{Xu}$ et al. 2012) may explain different responses to both environmental and endogenous aggressions, as well as gender- and gene-associated alterations in the MAPK pathway and PI3K/AKT pathway or in cell-cycle genes, such as p53 (TP53), reflecting in clinical differences.

\section{Concepts of tumor immunology}

A close relationship between immune response and cancer was first proposed by Virchow in 1863 (Balkwill \& Mantovani 2001). A few years later, Coley demonstrated that bacterial products were able to help inoperable cancer patients. The subsequent application of Bacillus CalmetteGuerin and other crude immunostimulants showed benefits that led to the regulatory approval of their use in the treatment of some solid tumors such as bladder cancer (Kirkwood et al. 2012). Thereafter, the capacity of the immune system to interfere with tumor progression has been proven by a series of clinical and epidemiological evidences. In fact, the success of Herceptin and Ipilimumab in treating breast and metastatic melanomas respectively has prompted scientists to go far beyond the frontiers in tumor immunology.

The field of tumor immunology is based on the fact that, during the tumorigenic process, malignant cells may express tumor-specific antigens and/or tumor-associated antigens. Tumor-associated antigens comprise gene products more frequently found in tumors, whereas tumor-specific antigens are gene products uniquely expressed in tumors (Lewis et al. 2003). These groups of antigens are target for immunotherapy, and new targets have actively been searched for all over the world. However, the absolute success of immunotherapy is impaired by tumor immune escape mechanisms.

Tumor cells are initially eliminated by the immune system before they become clinically detectable. This is then followed by an equilibrium phase, where a selection process for less immunogenic tumor variants takes place until tumor cells finally 'escape' from immune surveillance, as shown in Fig. 1 (Dunn et al. 2002).

One immune escape mechanism is active at the level of the tumor and can be ascribed to abnormalities in the expression of major histocompatibility complex (MHC) class I-restricted antigens, enabling tumors to take on a 'stealth' phenotype, hiding from immune cell detection (Poschke et al. 2011). The other mechanism results from the ability of the tumor to progress and 'sabotage' the host immune system. Certain tumors have the ability to use parts of the immune system to protect themselves against the host immune response. By doing so, tumors induce or recruit immune cells such as myeloid-derived suppressor cells (MDSCs) or regulatory $\mathrm{T}$ cells (Tregs). These cells physiologically serve as safeguards against overwhelming inflammation and lead to immune resolution (Poschke et al. 2011). The recruitment of these cells makes the microenvironment permissive for cell growth.

Published by Bioscientifica Ltd. 

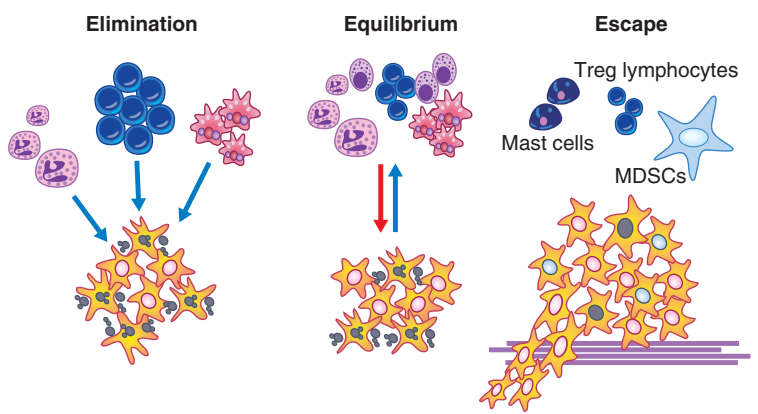

Figure 1

The Three Es theory. According to this theory, tumor cells are initially eliminated by the immune system. At this stage, tumors are not clinically detectable. This is then followed by an equilibrium phase, where a selection process for less immunogenic tumor variants takes place. At the third stage, tumor cells are able to 'escape' from immune surveillance.

The immune system is a cornerstone determinant of the tumor microenvironment, as shown in Fig. 2. Recent molecular biology studies conducted in cancer patients have revealed that the inflammatory profile of the tumor microenvironment and, in particular, the acute inflammation of host tissues, may define patient prognosis (Hsu et al. 2010, Suzuki et al. 2011, Chew et al. 2012). Unraveling the biology and composition of the inflammatory microenvironment is crucial to understand the nuances of carcinogenesis, as well as to predict the clinical outcome of cancer patients. Herein, we describe the inflammatory microenvironment in thyroid carcinogenesis by dividing the issue functionally into innate immunity, adaptive immunity, and molecules of the immune system.

\section{Innate immunity}

Different from the adaptive immune response, innate immunity comprises mechanisms that protect the host in a nonspecific manner (Murphy 2011). Innate immunity is sustained by cells such as neutrophils, eosinophils, and mast cells, constituting the first line of defensive response. These cells are bone marrow-derived, tissue-dwelling granulocytes found transiently in the blood circulation en route to tissue inflammatory sites (Davoine et al. 2013). Special attention has been paid to the neutrophilto-lymphocyte ratio (NLR).

NLR is derived from white blood cell differentiation counts (Chiang et al. 2012). Zahorec (2001) described the prognostic role of NLR in critically ill patients. Highest stress, marked neutrophilia, and lymphopenia were found in intensive care unit patients. Zahorec (2001) concluded that marked neutrophilia and lymphopenia are general innate immune responses to various stressful events. Marked neutrophilia and/or eosinophilia associated with neoplasia are relatively rare findings and are considered paraneoplastic manifestations only after excluding other

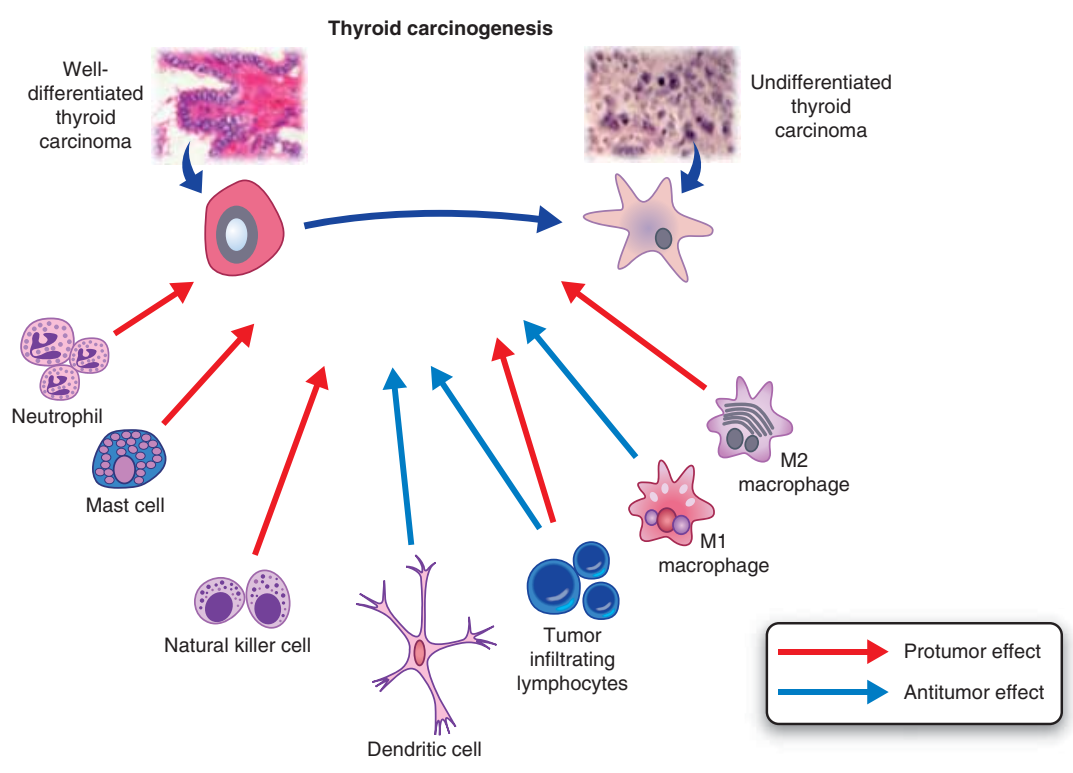

Figure 2

Immune cells engaged in antitumor or protumor immune response. Most of these cells may play a pleiotropic role in the inflammatory microenvironment. The balance of antitumor/protumor immune responses may be important for immune escape (cancer progression) or cancer elimination.

http://erc.endocrinology-journals.org DOI: 10.1530/ERC-13-0431
(C) 2014 Society for Endocrinology Printed in Great Britain
Published by Bioscientifica Ltd. 
causes, such as infections, allergy, collagen disease, vascular diseases, and concomitant malignant hematopoietic diseases (Hardy \& Balducci 1985). In addition, neutrophilia could represent a nonspecific response to cancer-related inflammation secondary to tissue destruction and cytokine release (Liu et al. 2013).

An association between high NLR and increased mortality or recurrence has been observed in various solid organ tumors (Hirashima et al. 1998, Walsh et al. 2005, Bhatti et al. 2010). Liu et al. (2013) investigated the total white blood cell and differential counts of 159 patients with DTC and 318 age- and sex-matched controls undergoing thyroidectomy for benign thyroid nodules. They found that cancer patients in the higher NLR tertile had a significantly larger tumor size and a high recurrence risk (Liu et al. 2013). There was no difference in NLR between patients having benign thyroid nodules and those having malignant thyroid nodules, suggesting that a high NLR is more important for tumor progression than for tumor initiation (Liu et al. 2013). In fact, experimental data indicate that activated neutrophils may directly and indirectly stimulate tumor growth (Fridlender et al. 2009). On the contrary, studying the NLRs of 26 patients with benign goiters, 31 patients with incidental papillary thyroid microcarcinoma, 26 patients preoperatively diagnosed with thyroid cancer, and 26 healthy controls, Seretis et al. (2013) found NLRs to be significantly elevated in patients with incidental papillary thyroid microcarcinoma and thyroid cancer, suggesting that the NLR should be considered an easily accessible biomarker for detecting incidental papillary thyroid microcarcinoma.

Since their discovery, a large number of studies have demonstrated natural killer (NK) cell-mediated lysis of different types of tumor cells in vitro, as well as NK celldependent elimination of many tumors in vivo (Ljunggren 2008). Phenotypically, NK cells are defined by the expression of CD16 and CD56 (NCAM1) surface markers (Cooper et al. 2001a). NK cells produce interferon $\gamma$ (IFN $\gamma$ (IFNG)), tumor necrosis factor $\alpha$ (TNF $\alpha$ (TNF)), TNF $\beta$ (LTA), and granulocyte-macrophage colony-stimulating factor (GMCSF (CSF2)) (Vivier et al. 2011). Gogali et al. investigated NK cell infiltration in the thyroid glands of 65 patients with PTC and 25 patients with thyroid nodular goiter (NG). They found a significantly increased number of NK cells in the PTC tissue samples than in the thyroid NG tissue samples. In addition, they demonstrated an inverse correlation between NK cell infiltration and tumor stage, with decreased NK cell infiltration in advanced stages of the disease (Gogali et al. 2012). This finding highlights the key role of evasion from the immune system in tumor progression and reinforces the weakness of the innate immune response toward cancer spread in advanced stages (Gogali et al. 2012).

However, does NK cell infiltration correspond to a homogeneous group of cells? The answer is probably no. There are two functionally different subsets of NK cells, CD56dim cells, which are cytotoxic; and CD56bright cells, which play an immunoregulatory role. These NK cell subsets present differences in their cytotoxic potential, cytokine production, and response to cytokine activation (Baume et al. 1992, Cooper et al. 2001b). The association of NK cells with cells that do not express MHC class I (e.g. tumor cells) makes the targets susceptible to NK cell-mediated lysis (Karre et al. 1986). Their ability to kill target cells, without prior sensitization, is regulated by the balance between stimulatory and inhibitory signals (Lanier 2008).

Liapi et al. (2013) investigated the distribution of CD3-CD16+CD56dim and CD3-CD16-CD56bright NK subpopulations in tissue and blood samples collected from patients with PTC and NG. Twenty-eight patients with PTC, 13 patients with NG, and 50 healthy donors were included in the study. The distribution of CD16-CD56bright and CD16+CD56dim NK cell subpopulations in the peripheral blood was similar in patients with PTC, patients with NG, and healthy donors. The number of CD16-CD56bright NK cells was increased in the tumor microenvironment of PTC tissue samples. Analysis of NK cell subpopulations in PTC tissue samples revealed that the number of CD16-CD56bright cells was higher than that of CD16+CD56dim cells. Comparison of NK cell subpopulations in the PTC and NG tissue samples revealed that the number of CD16+CD56dim cell was significantly higher in the NG tissue samples than in the PTC tissue samples. By contrast, CD16-CD56bright cells exhibited a higher infiltration in the PTC tissue samples than in the NG tissue samples, suggesting that an immunoregulatory pattern of $\mathrm{NK}$ cells is required for thyroid carcinogenesis (Liapi et al. 2013). Liapi et al. (2013) also found that the number of CD16+CD56dim NK cells was positively correlated with disease stage. The mean cell number in stage IVA was doubled when compared with that in stages I/II. The number of CD16-CD56bright NK cells was inversely correlated with disease stage and thyroid tissue infiltration, being greater in stages I/II. At first look, this result seems contradictory. However, it is well known that the tumor microenvironment of a stage IV tumor is quite different from that of an earlystage tumor (Cunha et al. 2012b). This fact should be considered along with the fact that NK cells migrating to lymphoid organs are CD56brigth NK cells and seem to be

Published by Bioscientifica Ltd. 
immature in comparison with CD56dim NK cells (Lanier et al. 1986). Recent studies have confirmed that CD56bright NK cells are precursors of the CD56dim subset (Chan et al. 2007, Ouyang et al. 2007). The tumor microenvironment can be the site where immature CD56bright cells transform into mature cytotoxic NK cells, but this developmental program is not entirely fixed, and mature NK cells can be re-educated by local and environmental factors (Freud et al. 2006). This could probably explain the gradual increase or decrease in the percentages of NK cell subpopulations correlating with the tumor stage.

When tissue homeostasis is perturbed, macrophages and mast cells release soluble factors such as cytokines, chemokines, reactive oxygen species (ROS), and bioactive mediators such as histamine, which induces leukocyte migration and infiltration at the site of lesion, characterizing the inflammation (de Visser et al. 2006). When the resolution of this response fails, a disease can be initiated (Aggarwal et al. 2006, Medzhitov 2010). Active mast cells generate angiogenic factors such as vascular endothelial growth factor (VEGF), fibroblast growth factor, histamine, heparin, matrix metallopeptidase 9, and several proteases, in addition to leading to the release of more cytokines and chemokines (Ribatti et al. 2001). These data suggest that mast cells are critically important for tumor progression. In fact, Melillo et al. (2010) showed that human PTC tissues, but not normal thyroid tissues, present an intense mast cell infiltrate and that its intensity is positively correlated with the invasive behavior of thyroid carcinomas. They also found that thyroid carcinoma cell cultures are mast cell chemoattractants mediated by VEGFA. When injected in the tail vein of immunodeficient mice, mast cells were found to be recruited to thyroid cancer cell xenografts. Moreover, when thyroid cancer cells were treated with conditioned media from mast cells, they exhibited higher proliferation rate, survival capacity, and invasive ability. The proliferation of thyroid cancer cells and their vascularization were reverted by sodium cromoglycate (Cromolyn), a specific MC degranulation inhibitor, suggesting that mast cells are cornerstone elements in the inflammatory microenvironment of thyroid cancer (Melillo et al. 2010). Proietti et al. (2011) evaluated the presence of mast cells in 91 consecutive cases of follicular variant of PTC (FVPTC) and 44 cases of thyroid adenoma. They found that mast cells were highly expressed in the peritumoral compartment of FVPTCs. There was also a significant correlation between the abundance of mast cells and the infiltrative pattern of the tumor in only the FVPTC group.

Inflammation occurring in the tumor microenvironment is characterized by leukocyte infiltration, where it varies in subset composition and distribution (Liotti et al. 2012). Cancer cells recruit monocytes from circulation. Herein, monocytes are induced to differentiate into macrophages by chemotactic factors (Vendramini-Costa \& Carvalho 2012). Phenotypically, macrophages can be recognized by the expression of CD68. Functionally, there are two different subsets of macrophages: M1 and M2. The main function of M1 is phagocytosis in response to bacterial stimuli and/or T helper 1 (Th1) cytokines, while the main function of M2 is immunosuppression and trophic activity in response to Th2 cytokines (Mantovani et al. 2002, Caillou et al. 2011).

Herrmann et al. (1994) observed that 75 thyroid carcinomas of follicular cell origin presented rising levels of CD68-positive cell infiltration associated with dedifferentiation. Ryder et al. (2008) investigated tumorassociated macrophages (TAMs) in 90 patients with different histological presentations of thyroid carcinoma. An increased number of TAMs in PDTC was found to be associated with capsular invasion, extrathyroidal extension, and decreased cancer-related survival when compared with PDTC with a low density of TAMs, suggesting that TAMs could be associated with disease progression. In fact, the same group experimentally demonstrated that TAMs promote PTC progression (Ryder et al. 2013). Using BRAF-induced PTC mouse models, they observed that the conditional activation of BRAF in the thyroids of adult mice induces PTCs, which express macrophage chemoattractants and are densely populated with TAMs. When TAMs were depleted, PTC initiation was impaired. Phenotypic analysis demonstrated an increased expression of M2-related genes such as $\mathrm{Ccr} 2$, arginase 1, Ccl22, and Il10, whereas the expression of M1-specific markers (Il12 (Il12b) and Ros (Ros1)) was not increased. Interestingly, selectively depleted TAMs during advanced stages of PTC induce tumor regression, and CSF1/CSF1R signaling can be pharmacologically targeted to impair PTC initiation (Ryder etal. 2013). These results suggest that TAMs may be rational therapeutic targets for patients with refractory advanced PTCs, particularly for those with PDTC and ATC.

Do macrophages play the same role in PDTC and wellDTC? They probably do not. We studied 398 patients with DTC and 132 with nonmalignant tissues (Cunha et al. $2012 b$ ). We found TAMs more frequently in more aggressive cases, with metastasis at diagnosis; however, paradoxically, macrophage infiltration was correlated with improved disease-free survival (Cunha et al. 2012b). As a protumorigenic role was proven previously, how to explain the apparent conflicting results? It is possible that

Published by Bioscientifica Ltd. 
these different results are related to different microenvironments, as shown in Fig. 3 (Ryder et al. 2008). In fact, Fiumara et al. (1997) studied 121 well-differentiated PTC samples and found tumors with TAMs and in situ evidence of active neoplastic cell phagocytosis. Neoplastic cell phagocytosis by macrophages was positively correlated with the infiltration of both lymphocytes and dendritic cells (DCs), whereas it was negatively correlated with vascular invasion (Fiumara et al. 1997). They also found a trend of reduced risk of distant metastases at follow-up in cases with TAMs that, in addition, was associated with lymphocyte infiltration, confirming the complexity of the immunological host reaction to thyroid cancer phenomenon (Fiumara et al. 1997, Cunha et al. 2012b).

\section{Adaptive immunity}

Granulocytes and macrophages represent the effector mechanisms of innate immunity. Unfortunately, they cannot always eliminate infectious agents or even efficiently combat tumor development. Conversely, cells of the innate immune system play a crucial role in the initiation and subsequent direction of adaptive immune responses that are mediated by lymphocytes (Murphy 2011). The lymphocytes of the adaptive immune system have evolved to provide a more versatile defense system, which, in addition, provides increased protection against subsequent reinfection with the same pathogen (Murphy 2011).

How do tumor-infiltrating lymphocytes (TILs) interfere with tumor progression? CD4 + T cells are central to the

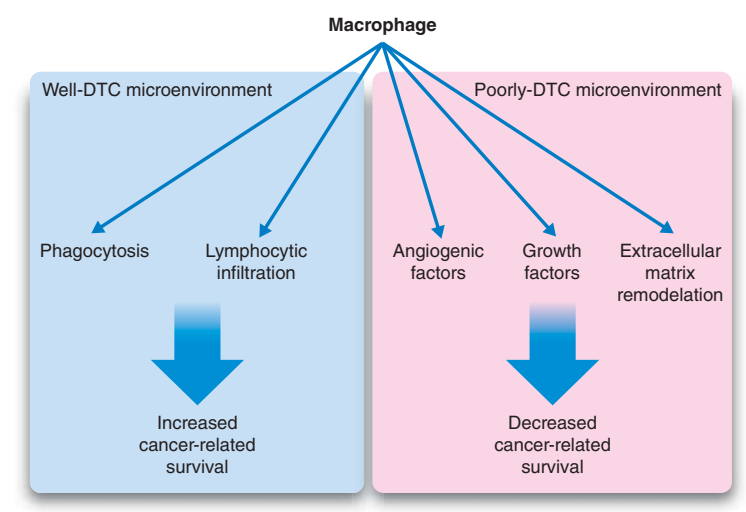

Figure 3

Macrophages and their complex role in thyroid carcinogenesis. The role of macrophages probably depends on the molecular profile of tumor microenvironment. In poorly differentiated tumors, protumor functions are highlighted, whereas well-differentiated cancer microenvironment may support stimuli that are able to elicit antitumor responses. successful orchestration of the immune response. Naive $\mathrm{CD} 4+\mathrm{T}$ cells differentiate into one of at least four functionally distinct forms: Th1, Th2, Th17, or Tregs. In general, Tregs are identified as FoxP3 + lymphocytes and are thought to contribute to tumor-specific T-cell tolerance (Zhou \& Levitsky 2007). The recent discovery of Th17 cells and their important role in host protection against infectious pathogens and in the pathogenesis of various inflammatory and autoimmune diseases have resulted in an explosion of immunological research. However, their role in human cancer is still under investigation (Su et al. 2010).

A mixture of lymphocytes are frequently found within and surrounding primary thyroid tumors (Modi et al. 2003, French et al. 2010). Villagelin et al. investigated 157 consecutive patients. They were classified by the degree of lymphocyte infiltration. Lymphocyte infiltration was classified as diffuse, peritumoral (only in or around the tumor), or absent. After a mean follow-up period of 8 years, they observed a significantly high recurrence in the absent lymphocyte infiltration group than in patients in the diffuse and peritumoral lymphocyte infiltration groups, suggesting that the presence of lymphocytes in the tumor microenvironment may favor the prognosis of patients with DTC (Villagelin et al. 2011), confirming previous reports (Matsubayashi et al. 1995, Gupta et al. 2001, Modi et al. 2003). Conversely, 100 PTC patients were analyzed for background thyroiditis and TILs by French et al. (2010). Patients with TILs exhibited higher disease stage and increased incidence of invasion and lymph node metastasis when compared with patients without lymphocytes or with background thyroiditis. The authors attributed these different results to the fact that concurrent thyroiditis would overshadow the real effect of lymphocytes on tumor progression. It is worth noting that considering only the presence and absence of TILs may obscure the functional and phenotypic diversity adjacent to different lymphocyte subsets.

To define the subset of lymphocytes found in association with PTC, French et al. (2010) analyzed primary tumors from ten patients with evident TILs by immunohistofluorescence. CD4 + T-cell frequency was found to be correlated with tumor size, Treg frequency with lymph node metastases, and CD8:Treg ratio inversely with tumor size. Our data demonstrated that the presence of concurrent chronic lymphocytic thyroiditis and infiltration of $\mathrm{CD} 4+, \mathrm{CD} 8+, \mathrm{CD} 20+$, Th17, and Treg cells are associated with favorable prognostic features in patients with DTC. Immune cells were found to infiltrate malignant tissues more often than benign lesions,

Published by Bioscientifica Ltd. 
suggesting an immune reaction of the organism against transformed cells (Cunha et al. 2012b). Nevertheless, how the immune system does act is not that simple. In fact, the effect of the immune system on patient outcome seems to result from complex interactions between tumor and immune system cells.

Antitumor immune response is thought to be related to tumor antigenicity. In fact, a correlation between protein expression profile and immune cell infiltration in DTC was observed (Bruland et al. 2009). Some researchers have suggested that the expression of MUC1, NIS (SLC5A5), ATM, PTEN, and CD56 might indicate tumor differentiation and tumor progression, demonstrating tumor antigenicity (Larson et al. 2007, El Demellawy et al. 2008, Morari et al. 2010). However, whether these markers are really associated with DTC immune response is still not clear. Aiming to examine the putative association between tumor molecular profile and TIL, TAM, and MDSC patterns, we investigated 398 patients whose tissue samples were maintained in the tissue bank of the institution. Thyroid carcinoma was diagnosed in 266 patients: 253 with PTCs and 13 with follicular carcinomas. We also obtained 132 normal or benign thyroid tissue samples. Immune cell infiltration was closely associated with the immunohistochemical profile of the DTC specimens examined, including CD56, NIS, MUC1, PTEN, ATM, and B7H1 (CD274) (Cunha et al. 2012a).

The immune response rarely is enough to eliminate tumors, and the reason for this is the existence of immune escape mechanisms. One of these mechanisms is the upregulation of $\mathrm{B} 7 \mathrm{H} 1$ expression. $\mathrm{B} 7 \mathrm{H} 1$ is a cell-surface glycoprotein that may be involved in the regulation of local inflammatory responses, and aberrant tumor expression of $\mathrm{B} 7 \mathrm{H} 1$ is thought to be associated with the inhibition of the immune system, as shown in Fig. 4 (Hamanishi et al. 2007). The expression of B7H1 in tumor cells has been reported to be associated with a poor prognosis in some epithelial cancers (Thompson et al. 2006). We demonstrated that the expression of both B7H1 protein and B7H1 mRNA is upregulated in DTCs, contrasting with the low levels displayed by benign tissues (Cunha et al. 2013). This result suggests that tumor cells may acquire $\mathrm{B} 7 \mathrm{H} 1$ expression during the tumorigenic process. We also observed an association between high B7H1 mRNA levels and the presence of some features of tumor aggressiveness, such as higher stages at presentation and increased age at diagnosis, suggesting that high levels of B7H1 expression may help identifying individuals who need a more aggressive approach (Cunha et al. 2013). We also studied the expression of $\mathrm{B} 7 \mathrm{H} 1$ in 18 patients with

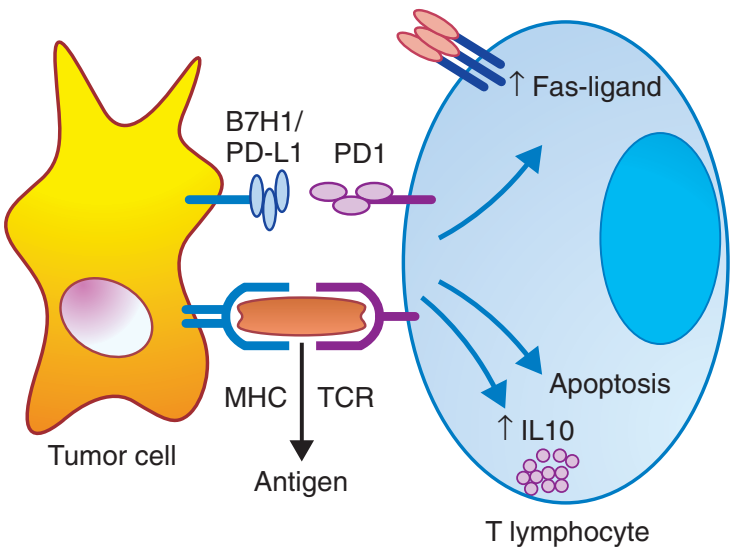

Figure 4

Constitutive expression of B7H1 by exhausted T cells. Tumor cells may acquire $\mathrm{B} 7 \mathrm{H} 1$. The interaction between tumor cells and $\mathrm{T}$ lymphocytes may induce an inhibition of the immune response mediated by $\mathrm{B} 7 \mathrm{H} 1$ expression. B7H1 is associated with IL10 production, induction of Fas ligand expression, and high apoptosis rate.

lymph node metastasis at diagnosis. Paired primary tumor and lymph node metastatic tissue samples were obtained from all the patients. We observed that the lymph node metastatic tissue samples had lower levels of B7H1 than the primary tumor tissue samples, indicating T-cell exhaustion (Cunha et al. 2013). French et al. (2012) have recently described high levels of IFN $+/ C D 8+T$ cells in 12 metastatic lymph node tissue samples excised during the initial surgery at patient presentation. The authors found that proliferating lymphocytes were evident in tumor-involved lymph node metastases that were enriched with PD1 (ligand of B7H1)+lymphocytes (French et al. 2012). They hypothesized that the presence of metastases does not arrest and may, on the contrary, promote an IFN + response, suggesting the generation of an antitumor response, which may impair tumor evasion. In fact, this could explain the decrease in B7H1 expression that we observed in our matched metastases, suggesting that T-cell exhaustion is a mechanism of tumor progression.

The main players within the context of innate and adaptive immunity are DCs, which induce, coordinate, and regulate the system (Steinman 1991, Banchereau et al. 2000). DCs are highly potent antigen-presenting cells with the unique ability of taking up and processing antigens in peripheral blood and tissues. They can migrate into the draining lymph nodes, where they present antigens to naive $\mathrm{T}$ lymphocytes and thus induce a cellular immune response involving CD4+ Th1 cells, cytotoxic CD8+ T cells, and B cells (Schott 2006). As DCs can modulate the

Published by Bioscientifica Ltd. 
whole immune repertoire, these cells are instrumental in the understanding of the inflammatory tumor microenvironment.

The importance of DCs in PTC was documented by an early study showing that patients with a dense infiltrate of S-100+ DCs in the tumor had a more favorable prognosis irrespective of other morphological and clinical features (Schroder et al. 1988). A series of 527 consecutive cases of thyroid carcinoma were investigated by Ugolini et al. aiming to detect DC infiltration. They found that the intratumoral inflammatory infiltrate (usually composed by mixtures of $\mathrm{CD} 4+, \mathrm{CD} 8+$, and $\mathrm{CD} 20+$ cells) was strongly reduced or absent in poorly differentiated and undifferentiated histotypes of thyroid carcinoma. DCs were most frequently detected in PTC cases (classical, follicular, and tall cell variants) and markedly reduced in poorly differentiated and undifferentiated tumors, pointing to the protective role of DCs and infiltrating lymphocytes against thyroid tumors (Ugolini et al. 2007). In addition, Hilly et al. (2013) have recently demonstrated that DC density in papillary carcinoma is correlated with the concurrent thyroiditis grade and DC density in the surrounding areas of thyroiditis. These data suggest that the infiltration of DCs is part of a more complex series of outcome events that comprises lymphocyte infiltration and thyroiditis establishment.

Proietti et al. (2011) studied the infiltration of both immature CD1a+ DCs and mature DC-Lamp+. In the intratumoral or peritumoral area, the expression of immature, but not mature, DCs was more frequently found in FVPTCs than in adenomas. Pusztaszeri et al. quantitatively assessed the presence of DCs that were positive for CD1a in the cytological samples of 31 histologically confirmed PTCs and in a control group of 29 benign thyroid nodules. CD1a-positive DCs were identified in $97 \%$ of the PTCs in thyroid cytology specimens. By contrast, only $31 \%$ of benign thyroid nodules had CD1a-positive DCs (Pusztaszeri et al. 2013). The significant presence of CD1a-positive DCs in PTCs suggests that these cells are recruited during malignant transformation.

Aiming to investigate this issue, Scarpino et al. established primary cultures of neoplastic thyroid cells and normal cells (from the tumor-free contralateral lobe of the same patients) obtained from eight thyroids removed surgically. Surprisingly, they found that normal thyroid cells and tumor cells were equally effective at releasing chemotactic activity for DCs in culture supernatants (Scarpino et al. 1999). This finding is in conflict with the observation that DCs are rare in normal thyroid tissues and raises the possibility that culture conditions may trigger stimulatory signals for normal thyroid cells. In fact, the same group had previously demonstrated that normal thyroid cells of primary cultures, but not normal thyroid cells of tissue sections, express high levels of MET protein and urokinase-type plasminogen activator receptor (uPAR (PLAUR)) and both factors are engaged in DC recruitment (Ruco et al. 1996, Zanetti et al. 1998, Scarpino et al. 1999). MET protein is present in Hürthle cells of Hashimoto's thyroiditis and hyperfunctioning thyrocytes of Graves' disease (Ruco et al. 1996, Zanetti et al. 1998), indicating that the upregulation of MET receptor is an early event in thyroid cell alteration. This result corroborates the rare infiltration of DCs in benign thyroid lesions (Pusztaszeri et al. 2013).

\section{Immune system molecules in thyroid carcinogenesis}

The immune system can produce or stimulate the production of many molecules in response to aggressive or nonproper features. These molecules are called cytokines and may be produced by signals of the innate or adaptive immune response for several types of cells. Cytokines influence the activation, growth, and differentiation of several different target cells, and more than 100 types of cytokines have been identified (Yadav et al. 2012). Table 1 summarizes the function of some cytokines. Failure to contain or impede injury can lead to persistent and excessive cytokine production, ultimately leading to harmful tissue destruction. Therefore, the balance of the host reactions to cellular stress, which will cause their production, might affect different stages of cancer (Dranoff 2004).

\section{Interferon $\gamma$}

IFN $\gamma$ is a cytokine that mediates pleiotropic effects on the innate and adaptive responses to infection, and its deficiency or deficiency of its receptor has been reported to be related to the development of more tumors in mice exposed to chemical carcinogens (Bach et al. 1997, Smyth et al. 2000). IFN $\gamma$ has long been reported to be associated with cytostatic/cytotoxic and antitumor functions (Brown et al. 1987). Kaplan et al. (1998) reported that approximately one-third of melanoma and lung adenocarcinoma cell lines have inactivating mutations in IFN $\gamma$ pathway components, suggesting that tumor insensitivity to this cytokine could be an evasion mechanism. Recombinant IFN $\gamma$ treatment was subsequently tested to

Published by Bioscientifica Ltd. 
Table 1 Summary of the effects of some cytokines and the cells in which they are produced

\begin{tabular}{|c|c|c|}
\hline Molecule & Producer & Effect \\
\hline $\mathrm{IFN} \gamma$ & $\begin{array}{l}\text { Activated macrophages } \\
\text { Tumor cells }\end{array}$ & $\begin{array}{l}\text { Cytostatic/cytotoxic } \\
\text { Cytoproliferative } \\
\text { Stimulation of the secretion of } \\
\text { Th1 cytokines }\end{array}$ \\
\hline TNF & $\begin{array}{l}\text { Activated macrophages } \\
\text { CD4+ lymphocytes } \\
\text { NK cells } \\
\text { Tumor cells }\end{array}$ & $\begin{array}{l}\text { Apoptosis } \\
\text { Necrosis } \\
\text { Angiogenesis } \\
\text { Immune cell activation } \\
\text { Differentiation } \\
\text { Cell migration } \\
\text { Cachexia }\end{array}$ \\
\hline TGF $\beta$ & $\begin{array}{l}\text { Myeloid cells } \\
\text { T lymphocytes } \\
\text { Tumor cells }\end{array}$ & $\begin{array}{l}\text { Epithelial-to-mesenchymal transition } \\
\text { Metastasis } \\
\text { Immune tolerance } \\
\text { Cell survival }\end{array}$ \\
\hline IL1 & $\begin{array}{l}\text { Leukocytes } \\
\text { Tumor cells }\end{array}$ & $\begin{array}{l}\text { Proliferation } \\
\text { Differentiation } \\
\text { Proangiogenic } \\
\text { Prometastatic } \\
\text { Production of inflammatory molecules }\end{array}$ \\
\hline IL2 & $\begin{array}{l}\text { CD4+ lymphocytes } \\
\text { CD8 + lymphocytes } \\
\text { Activated DCs } \\
\text { Activated NK cells }\end{array}$ & $\begin{array}{l}\text { Stimulation of antibody synthesis } \\
\text { Proliferation of NK cells } \\
\text { Differentiation of NK cells }\end{array}$ \\
\hline IL4 & $\begin{array}{l}\text { Th2 cells } \\
\text { Basophils } \\
\text { Mast cells } \\
\text { Eosinophils } \\
\text { Tumor cells }\end{array}$ & $\begin{array}{l}\text { Response against helminths } \\
\text { Suppression of Th1 cells } \\
\text { Induction of IgE class switching in B cells } \\
\text { Expression of class II MHC } \\
\text { Expression of B-cell receptors } \\
\text { Prolongation of the lifespans of T and B cells } \\
\text { Mediation of tissue adhesion } \\
\text { and inflammation }\end{array}$ \\
\hline IL6 & $\begin{array}{l}\text { Endothelial cells } \\
\text { Fibroblasts } \\
\text { Monocytes } \\
\text { Macrophages }\end{array}$ & $\begin{array}{l}\text { Leukocyte trafficking } \\
\text { Leukocyte activation } \\
\text { Induction of acute-phase protein production } \\
\text { T-cell proliferation } \\
\text { B-cell differentiation } \\
\text { B-cell survival }\end{array}$ \\
\hline IL10 & $\begin{array}{l}\text { Monocytes } \\
\text { T cells (mainly Th2 cells) } \\
\text { B cells } \\
\text { NK cells } \\
\text { Macrophages } \\
\text { DCs } \\
\text { Mast cells } \\
\text { Tumor cells }\end{array}$ & $\begin{array}{l}\text { Immune resolution } \\
\text { Immune tolerance } \\
\text { Impairment of T-cell activation } \\
\text { Survival, proliferation, and differentiation } \\
\text { of human B cells }\end{array}$ \\
\hline Leptin & Adipocytes & $\begin{array}{l}\text { Activation of monocytes and macrophages } \\
\text { Angiogenesis } \\
\text { Suppression of the production of } \\
\text { anti-inflammatory cytokines }\end{array}$ \\
\hline Resistin & $\begin{array}{l}\text { Adipocytes } \\
\text { Monocytes } \\
\text { Macrophages }\end{array}$ & Production of IL6 and TNF $\alpha$ \\
\hline Adiponectin & Adipocytes & $\begin{array}{l}\text { Insulin sensitivity } \\
\text { Inhibition of LPS-induced TNF } \alpha \text { production } \\
\text { in macrophages } \\
\text { Differentiation of M2 macrophages } \\
\text { Stimulation of the production of } \\
\text { anti-inflammatory IL10 } \\
\text { Modulation of T-cell activation and } \\
\text { inflammatory function of NK cells }\end{array}$ \\
\hline
\end{tabular}

\section{References}

Brown et al. (1987) and Rotondi et al. (2013)

Beutler et al. (1985), Wajant (2009) and Lippitz (2013)

\section{Arsura et al. (2003), Bierie \& Moses (2006) and Fabregat et al. (2013)}

Akdis et al. (2011)

Waldmann (2006)

Howard et al. (1982) and Akdis et al. (2011)

Hirano et al. (1985) and Hurst et al. (2001)

Akdis et al. (2011)

Kwon \& Pessin (2013)

Bokarewa et al. (2005)

Yokota et al. (2000), Kumada et al. (2004), Takemura et al. (2007) and Li et al. (2009) http://erc.endocrinology-journals.org DOI: 10.1530/ERC-13-0431
(C) 2014 Society for Endocrinology Printed in Great Britain
Published by Bioscientifica Ltd 
treat a variety of tumors: chronic myelogenous leukemia, bladder carcinoma, colorectal cancer, melanoma, ovarian cancer, and adult T-cell leukemia, but the results were considerably heterogeneous (Kurzrock et al. 1987, Kloke et al. 1992, Miller et al. 2009), suggesting that IFN $\gamma$ has, in fact, two faces: it can have cytostatic/cytotoxic and cytoproliferative effects, depending on the context, similar to transforming growth factor $\beta$ (TGF $\beta$ (TGFB1)) and TNF, which also display this kind of dual contrasting behaviors (Roberts \& Wakefield 2003, Wajant 2009). IFN $\gamma$ studies in thyroid tissues have been carried out more frequently in autoimmune diseases, such as Hashimoto's thyroiditis. Some authors have reported that transgenic mice expressing interferon in the thyroid gland develop numerous features of Hashimoto's thyroiditis, including goiter, disrupted thyroid architecture, long-lasting hypothyroidism, and Hürthle cell metaplasia, indicating that IFN $\gamma$ can transform a thyrocyte into a Hürthle cell by inducing the expression of an immunoproteasome component called LMP2 (PSMB6; Caturegli et al. 2000, Kimura et al. 2005, 2009). In a recent study, Rotondi et al. (2013) have shown that IFN $\gamma$ stimulates the secretion of CXCL10, a situation associated with Th1 T-cell infiltration typical of autoimmune thyroid disease (AITD), which is closely related to thyroid tumors, leading, in most cases, to a better prognosis of patients (Cunha \& Ward 2011, 2012). Conversely, the administration of TNF $\alpha$ has been shown to lead to high levels of CXCL8 (IL8), a chemokine that is not primarily involved in thyroid autoimmunity, but that might induce tumor-related inflammatory infiltrating lymphocytes in thyroid diseases.

\section{Tumor necrosis factor}

TNF has a central role in immune homeostasis, inflammation, and host defense. Depending on the cellular context, it can induce diverse processes such as apoptosis, necrosis, angiogenesis, and immune cell activation, differentiation, and migration (Wajant 2009). TNF can also modulate cachexia, mediating cancer-associated fatigue and muscle wasting by its proinflammatory properties (Beutler et al. 1985). TNF $\alpha$ and interleukin 1 (IL1) are described as acute-response cytokines. They activate vascular endothelial cells and induce endothelial cells to express adhesion molecules for neutrophils, monocytes, and lymphocytes (Lippitz 2013). Although TNF has a strong role in apoptosis and necrosis, systemic clinical tests with this factor have failed due to the severe inflammatory side effects associated with systemic TNF receptor activation (Wajant 2009). Nevertheless, safe local administration of TNF in combination with melphalan by isolated limb perfusion was tested as a treatment option for locally advanced soft limb sarcomas, and there are ongoing clinical studies aiming to identify antibodies able to restrict TNF activity to the tumor area or to inhibit the therapy-limiting side effects (van Horssen et al. 2006). Increased serum concentrations of TNF $\alpha$ were described in eight tumors: non-small-cell lung carcinoma (NSCLC), breast cancer, colorectal cancer, prostate cancer, chronic lymphocytic leukemia, malignant melanoma, nonHodgkin lymphoma, and gastric cancer (Lippitz 2013). These studies provide evidences that the production of TNF $\alpha$ in the tumor microenvironment can lead to direct DNA damage; has an apoptotic or antiapoptotic role and, depending on downstream signaling, mitogenic activity; can mediate tumor cell/stroma relationships; and can induce other cytokines and chemokines that promote tumor development (Vendramini-Costa \& Carvalho 2012). Zhang et al. (2013) have recently demonstrated that the administration of thyroid-stimulating hormone (TSH) can increase TNF $\alpha$ expression, which has already been reported to be related to the chemokine profile of tumor inflammation, possibly indicating that TNF $\alpha$ might play an indirect role in thyroid tumors by the inflammation that it stimulates (Rotondi et al. 2013). In Graves' disease, inflammatory mediators, such as ILs and TNF $\alpha$, stimulate the production of external thyroid-stimulating antibodies that bind to the TSH receptor (Baur et al. 2000, Davis 2008).

\section{Transforming growth factor $\beta$}

TGF $\beta$ is a member of the growth factor TGF $\beta$ superfamily, including bone morphogenetic protein, activins, inhibins, and anti-Müllerian hormone, among others, produced by cancer cells, myeloid cells, and T lymphocytes. TGF $\beta$ is best known for its antiproliferative effects, and its signaling is an important regulator of the epithelialto-mesenchymal transition and metastasis (Bierie \& Moses 2006). However, tumor cells develop mechanisms to overcome TGF $\beta$-induced suppressor effects. Once this occurs, cells may respond to this cytokine inducing other effects that contribute to tumor progression, such as immune tolerance that shields the tumor from immune surveillance (Vendramini-Costa \& Carvalho 2012, Fabregat et al. 2013). Numerous studies have established that deregulated activation of the NF- $\mathrm{BB}$ and PI3K/AKT pathways by TGF $\beta$ promotes cancer cell survival (Arsura et al. 2003, Lin et al. 2007). Interestingly, TGF $\beta$ routinely suppresses the activation of NF- $\kappa \mathrm{B}$ in normal epithelial

Published by Bioscientifica Ltd. 
cells by inducing their expression of $\mathrm{I} \kappa \mathrm{B} \alpha$ (NFKBIA; Nagumo et al. 2005, Sanchez-Capelo 2005). However, this event is inactivated during oncogenic progression, and TGF $\beta$ stimulation of late-stage cancers of the breast, prostate, and liver has been proven to result in NF- $\kappa \mathrm{B}$ activation, leading to the induction of prosurvival and tumorigenic gene expression profiles (Arsura et al. 2003). Both TGF $\beta$ mRNA and TGF $\beta$ protein are expressed in thyroid cells. There is evidence that iodine and TSH are regulators of this production. Experimental studies have shown that iodine excess leads to an increased mRNA expression of $T G F \beta$, stimulating protein synthesis (Yuasa et al. 1992, Cowin \& Bidey 1995). In addition, studies in rats treated with TRH showed that during the formation of goiter, there is an increase in Tgf $\beta$ gene expression (Morosini et al. 1996). Kimura et al. (1999) proved that goiter and DTC tissues exhibit a higher expression than normal tissues. In a more recent study, Eloy et al. (2012) have proposed a new division of malignant tumors, classifying them into well-circumscribed carcinomas (WCPTCs), ones lacking infiltrative features and lymph node metastasis, and poorly circumscribed carcinomas, ones having these characteristics. This allowed the authors to observe that TGF $\beta$ was less expressed in the center of WCPTCs and that this expression increased as they became invasive forms, also associated with SMAD4 and SMAD7 proteins, probably increasing the ability of these tumors to progress and invade. These findings provided new perspectives for the understanding of TGF $\beta$ mechanisms for tumor progression, as not only the classically studied pathways, such as PI3K/AKT and MAPK, appear to be involved in malignant TGF $\beta$ transformation, but also SMAD molecules might play a role in this event.

\section{Interleukins}

A large group of secreted proteins that bind to their specific receptors and play a role in the communication among leukocytes are called ILs, and they are divided into families based on sequence homology and receptor chain similarities or functional properties (Akdis 2011). Some of the immune system molecules, such as CD4+ Th cells, are classified according to the cytokine profile of the microenvironment where they are present, which is ultimately regulated by the expression of other cytokines, showing a dependence of some ILs on other cytokines to be produced (Fan et al. 1998, Akdis 2011). Such a profile might define the specific properties of the cells and their role in immune response to nonproper agents.
IL1 is a proinflammatory cytokine that mediates many inflammatory diseases and interferes in cell proliferation, differentiation, and function in innate and adaptive immunity (Akdis 2011). IL1 can be produced by neoplastic cells or by the microenvironment where it is present, stimulating the production of proangiogenic and prometastatic mediators (Lewis et al. 2006). As it has a role in proliferation and can also lead to the production of ROS and RNS, IL1 can favor the accumulation of mutations, increase the invasiveness of tumor cells that are existing already, activate the angiogenic machinery, and induce the production of inflammatory molecules, contributing to the spread of tumor cells (Apte et al. 2006). Thus, as expected, high levels of IL1 would be associated with a worse prognosis. In fact, the expression of IL1 has been shown to be upregulated in melanomas and colon, lung, head-and-neck, and gastric cancers (Perrier et al. 2009). With regard to thyroid tissues, Rebuffat et al. (2013) have recently demonstrated that IL1 $\beta$ (IL1B) modifies thyroid epithelial tightness by altering the expression and localization of junction proteins in Graves' and Hashimoto's diseases, suggesting that IL1 $\beta$ could play a role in the pathogenesis of thyroid autoimmunity. Alterations in serum concentrations of IL1 $\beta$ have been suggested to differentiate PTCs from atrophic thyroiditis (Kammoun-Krichen et al. 2012). The inheritance of the polymorphism rs2192752 in IL1 receptor (IL1R1) increases the risk of PTC, indicating an association of this IL with DTC (Park et al. 2012).

Several studies have also been conducted to test the efficacy of IL2 in stimulating the immune system of cancer patients, as the main functions of IL2 are as follows: regulating the growth of B cells, stimulating the synthesis of antibodies, and increasing the cytolytic capacity of cells, through the increase in NK cell proliferation (Waldmann 2006). As a matter of fact, recombinant human IL2 is used in immunotherapy for advanced renal cancers and melanomas and for treating AIDS associated with HIV (Akdis et al. 2011, Liang et al. 2012). The administration of high doses of IL2 is associated with a better response rate in the case of melanomas and renal cancers, leading to improvements in disease-free survival, although the side effects of IL2 administration are remarkably hard on most of the patients (Clement \& McDermott 2009, Halama et al. 2010).

IL4 is produced by Th2 cells, basophils, mast cells, and eosinophils and, similar to most of the cytokines, is able to regulate other immune molecules (Howard et al. 1982). IL4 is one of the most important cytokines for the differentiation of CD4+ cells into Th1 and Th2 cells, essential

Published by Bioscientifica Ltd 
effectors of immune responses (Akdis et al. 2011). Besides Th1 and Th2 cell production, IL4 also affects the phenotypes of $\mathrm{B}$ and $\mathrm{T}$ cells, leading to prolonged cell lifespans, which will affect tissue adhesion and inflammation (Akdis et al. 2011). Studies have long shown that IL4 has an inhibitory effect on the growth of human melanomas, renal cell carcinomas, and gastric cells (Hoon et al. 1991). On the contrary, IL4 and IL10 have been reported to exert a stimulatory effect on the growth of thyroid cancer cells. The production of IL4 and IL10 has been shown to be related to the promotion of thyroid tumor cell progression through the downregulation of BCL2 and BCL-XL (BCL2L1), leading to the death of a considerable number of cells (Stassi et al. 2003). Although through different mechanisms, Vella et al. (2004) suggested that concomitant Graves' disease and PTC that exhibited IL4 and IL10 expression were more likely to display apoptosis resistance, probably potentiating antiapoptotic factors, such as insulin-like growth factors. In the same way, Todaro et al. demonstrated that IL4 and IL10 upregulate cFLIP (CFLAR) and PED/PEA15, neutralizing the interaction of CD95L with CD95, which ultimately results in thyroid tumor cell survival and proliferation. The authors observed thyroid tumor cell extinction when they neutralized these cytokines, suggesting that they could be used as therapeutic targets (Todaro et al. 2006). In a recent study, Lee (2012) has described the induction of DCs from peripheral blood mononuclear cells purified from patients with thyroid cancer by culturing them in the presence of FL, GMCSF, IL4, and TNF $\alpha$. The authors provided morphological evidence that the co-culture of $\mathrm{T}$ cells/cancer tissues activated $\mathrm{T}$ cells and differentiated cytotoxic $\mathrm{T}$ lymphocytes. These cytotoxic $\mathrm{T}$ lymphocytes adhered to cancer tissues and lysed cancer tissues, suggesting that DCs could be used as potential vaccines in immunotherapy, resulting in minimum residual disease after the conventional treatments applied to cancer (Lee 2012).

IL6 is involved in both innate and acquired immunity and its production is affected by stimuli from other cytokines (IL1, IL17, and TNF $\alpha$; Akdis 2011). In innate immunity, IL6 is considered a regulator of acute-phase responses, through the activation of leukocytes and also the stimuli for the expression of acute-phase proteins (Hurst et al. 2001). IL6 also participates in acquired immunity, promoting B-cell differentiation and survival and plasma-cell production of antibodies (Hirano et al. 1985, Akdis 2011). There are strong positive associations between serum IL6 concentrations and tumor size, tumor stage, and disease progression in patients with gastric cancer, colorectal cancer, bone sarcoma, breast cancer, hepatocellular cancer, nasopharyngeal cancer, renal cell cancer, lung cancer, and melanoma (Niitsu et al. 2002, Chow et al. 2003, Nikiteas et al. 2005, Tas et al. 2005, Ahmed et al. 2006, Hsia et al. 2006, Egler et al. 2008, Ikeguchi et al. 2009). Although there are several evidences that IL6 is closely related to AITDs, its relationship with thyroid cancers has not been fully investigated (Gillespie et al. 2012, Popova et al. 2012, Beumer et al. 2013).

IL10 is an anti-inflammatory factor and an important regulator of several aspects of immune responses (Akdis 2011). It is very important in the microenvironment where it is located, since it inhibits the expression of many proinflammatory cytokines, chemokines, and chemokine receptors, thus influencing the production and effects of a large number of molecules, indirectly affecting T-cell activation (Akdis 2011). Circulating concentrations of IL10 were investigated in different cancer types and were found to be associated with adverse disease stage or with negative prognosis in bone sarcoma, diffuse large B-cell lymphoma, gastric cancer, colon cancer, Hodgkin's lymphoma, hepatocellular cancer, melanoma, renal cell cancer, NSCLC, and pancreatic cancer (Sato et al. 1996, Onishi et al. 1999, Suzuki et al. 2001, Chen et al. 2013). Our group showed that the inheritance of a G allele at IL $10-1082 \mathrm{~A} / \mathrm{G}$ polymorphism may favor concurrent thyroid autoimmunity in DTC patients, and this autoimmunity may favor a better prognosis of these patients (Cunha et al. 2011). In addition, Yu et al. (2013) demonstrated that the concentration of IL10 was significantly higher in patients with PTCs associated with multinodular goiter (MNG) than in patients with MNG alone, suggesting that cancer patients would have a specific type of Treg that affects antitumor responses and may facilitate disease progression and worse prognosis.

\section{Adipokines}

Adipokines or adipocytokines are cytokines produced by the adipose tissue. They have different functions, such as regulation of appetite and energy balance, immunity, insulin sensitivity, angiogenesis, inflammation and acutephase response, blood pressure, and lipid metabolism (Kwon \& Pessin 2013). Many current researches involve adipokines such as leptin, adiponectin, and resistin, considering that these adipokines have a direct relationship with the adipose tissue and are directly involved in changes in the immune response and insulin resistance, which can be a risk factor of several diseases associated

Published by Bioscientifica Ltd 
with obesity, such as diabetes. Our group has obtained preliminary data suggesting a relationship between obesity and DTC development (Marcello et al. 2012), but the molecular mechanisms involved in this relationship are not yet very well understood, although recent literature has been pointing to insulin resistance and potentially adipokines as probable connectors.

The structure of leptin is similar to that of IL2, IL6, and granulocyte colony-stimulating factor, and similar to other cytokines, it can activate monocytes and macrophages, stimulate VEGF and angiogenesis, and suppress the production of anti-inflammatory cytokines (Kwon \& Pessin 2013). The induction of inflammatory responses by leptin involves its receptor $\mathrm{b}\left(\mathrm{LepR}_{\mathrm{b}}\right), \mathrm{JAK} 2$, and STAT3 signaling pathway (Kwon \& Pessin 2013), and all these molecules ultimately have an effect on the PI3K/AKT and MAPK signaling pathways. Thus, leptin interacts with several factors that participate in the main signaling pathways of DTCs and could represent one of the links between obesity and DTC. The expression of leptin and its receptor, OBR (LEPR), has already been reported to be associated with a high risk of lymph node metastases, worsening the prognosis of patients, suggesting that the participation of this adipokine in DTCs might be important for their progression (Cheng et al. 2010).

Resistin is primarily related to insulin resistance by the activation of SOCS3 and the suppression of insulinmediated signaling in rat adipocytes (Steppan et al. 2005), but in humans this association is not always true. This might be because resistin is produced not only by adipocytes (as in rodents) but also by monocytes and macrophages in humans (Kwon \& Pessin 2013). In macrophages, the expression of resistin is induced by inflammatory cytokines such as IL1 $\beta$, IL6, TNF $\alpha$, and lipopolysaccharide (LPS). In human peripheral mononuclear cells, resistin stimulates the production of IL6 and TNF $\alpha$ through the NF- $\mathrm{BB}$ signaling pathway (Bokarewa et al. 2005). Similar to leptin, resistin also binds to TLR4, activating JNK and p38 MAPK to induce insulin resistance (Benomar et al. 2013). The expression of resistin has been reported to be associated with the increased proliferation of prostate cancer cells by the stimulation of the AKT pathway, a widely studied pathway in follicular thyroid tumors (Kim et al. 2011). There are also reports of the influence of resistin on breast cancer cells (Kang et al. 2007, Sun et al. 2010). As for other adipokines, there are evidences that the expression of resistin can be modulated by the presence of polymorphisms in its gene and gene receptor (Chen et al. 2010). Eke Koyuncu et al. (2013) have recently demonstrated significant correlations between resistin and TSH levels in hyperthyroid individuals, suggesting that the levels of this cytokine are directly related to thyroid dysfunction.

Adiponectin is highly expressed by adipocytes with potent anti-inflammatory properties and its expression can be suppressed by proinflammatory factors such as TNFa, IL6, ROS, and hypoxia (Li et al. 2009). The administration of adiponectin or its overexpression in transgenic mice results in improved insulin sensitivity, inhibits LPS-induced TNF $\alpha$ production in macrophages, promotes the differentiation of anti-inflammatory M2 macrophages and phagocytosis to remove apoptotic cells, stimulates the production of anti-inflammatory IL10, and also modulates T-cell activation and inflammatory function of NK cells (Yokota et al. 2000, Kumada et al. 2004, Takemura et al. 2007). Recently, Mitsiades et al. (2011) have demonstrated that serum adiponectin concentrations are inversely correlated with DTC, exerting a protective effect against the development of this cancer. Furthermore, the authors demonstrated that thyroid tissues express the receptors ADIPOR1 and ADIPOR2, which facilitate the entrance and functioning of adiponectin, suggesting a relationship between this cytokine and thyroid tissues.

In summary, DTCs are enriched with multiple inflammatory cells and both innate and adaptive immune responses seem to be engaged in thyroid carcinogenesis. In addition, the molecular pattern of cytokines and chemokines helps to explain the involvement of the immune system in tumor progression. The first attempt to use the immune system as a tool for treating patients with thyroid cancer was made in 1975. Active immunotherapy was applied to three patients. Two of them, who were in the terminal stage of the disease, could not develop generalized cell-mediated immunity. One patient developed in vitro evidence of cell-mediated immunity against cancer tissue antigens, associated with a decrease in tumor size (Amino et al. 1975). Unfortunately, more than 30 years later, no relevant successful result has been obtained for thyroid immunotherapy. On the other hand, the inflammatory microenvironment may help to identify more aggressive tumors and patients who would benefit from a more invasive approach, probably sparing the vast majority of patients with an indolent disease from unnecessary procedures.

\section{Declaration of interest}

The authors declare that there is no conflict of interest that could be perceived as prejudicing the impartiality of the review reported.

Published by Bioscientifica Ltd. 


\section{Funding}

This study was supported by the State of São Paulo Research Foundation (Fapesp).

\section{Author contribution statement}

All the authors of this review directly participated in the planning, analysis, and writing of the article and read and approved the final version submitted.

\section{Acknowledgements}

The authors thank Etna Macário of the Faculty of Medical Sciences for her valuable suggestions and insights.

\section{References}

Aggarwal BB, Shishodia S, Sandur SK, Pandey MK \& Sethi G 2006 Inflammation and cancer: how hot is the link? Biochemical Pharmacology 72 1605-1621. (doi:10.1016/j.bcp.2006.06.029)

Ahmed OI, Adel AM, Diab DR \& Gobran NS 2006 Prognostic value of serum level of interleukin- 6 and interleukin- 8 in metastatic breast cancer patients. Egyptian Journal of Immunology 13 61-68.

Akdis M 2011 Interleukins, from 1 to 37, and interferon- $\gamma$ : receptors, functions, and roles in diseases (vol 127, pg 701, 2011). Journal of Allergy and Clinical Immunology 128 739. (doi:10.1016/j.jaci.2011.07.022)

Akdis M, Burgler S, Crameri R, Eiwegger T, Fujita H, Gomez E, Klunker S, Meyer N, O'Mahony L, Palomares O et al. 2011 Interleukins, from 1 to 37 , and interferon- $\gamma$ : receptors, functions, and roles in diseases. Journal of Allergy and Clinical Immunology 127 701-717. (doi:10.1016/ j.jaci.2010.11.050)

Amino N, Pysher T, Cohen EP \& Degroot LJ 1975 Immunologic aspects of human thyroid cancer. Humoral and cell-mediated immunity, and a trial of immunotherapy. Cancer 36 963-973. (doi:10.1002/1097-0142 (197509)36:3 < 963::AID-CNCR2820360319>3.0.CO;2-3)

Apte RN, Krelin Y, Song X, Dotan S, Recih E, Elkabets M, Carmi Y, Dvorkin T, White RM, Gayvoronsky L et al. 2006 Effects of micro-environmentand malignant cell-derived interleukin-1 in carcinogenesis, tumour invasiveness and tumour-host interactions. European Journal of Cancer 42 751-759. (doi:10.1016/j.ejca.2006.01.010)

Arsura M, Panta GR, Bilyeu JD, Cavin LG, Sovak MA, Oliver AA, Factor V, Heuchel R, Mercurio F, Thorgeirsson SS et al. 2003 Transient activation of NF- $\kappa$ B through a TAK1/IKK kinase pathway by TGF- $\beta 1$ inhibits AP-1/SMAD signaling and apoptosis: implications in liver tumor formation. Oncogene 22 412-425. (doi:10.1038/sj.onc.1206132)

Bach EA, Aguet M \& Schreiber RD 1997 The IFN $\gamma$ receptor: a paradigm for cytokine receptor signaling. Annual Review of Immunology 15563. (doi:10.1146/annurev.immunol.15.1.563)

Balkwill F \& Mantovani A 2001 Inflammation and cancer: back to Virchow? Lancet $\mathbf{3 5 7}$ 539-545.

Banchereau J, Briere F, Caux C, Davoust J, Lebecque S, Liu YJ, Pulendran B \& Palucka K 2000 Immunobiology of dendritic cells. Annual Review of Immunology 18 767-811. (doi:10.1146/annurev.immunol.18.1.767)

Baume DM, Robertson MJ, Levine H, Manley TJ, Schow PW \& Ritz J 1992 Differential responses to interleukin 2 define functionally distinct subsets of human natural killer cells. European Journal of Immunology 22 1-6. (doi:10.1002/eji.1830220102)

Baur A, Bauer K, Jarry H \& Kohrle J 2000 Effects of proinflammatory cytokines on anterior pituitary $5^{\prime}$-deiodinase type I and type II. Journal of Endocrinology 167 505-515. (doi:10.1677/joe.0.1670505)

Benomar Y, Gertler A, De Lacy P, Crepin D, Hamouda HO, Riffault L \& Taouis M 2013 Central resistin overexposure induces insulin resistance through Toll-like receptor 4. Diabetes 62 102-114. (doi:10.2337/db12-0237)

Beumer W, Effraimidis G, Drexhage RC, Wiersinga WM \& Drexhage HA 2013 Changes in serum adhesion molecules, chemokines, cytokines, and tissue remodeling factors in euthyroid women without thyroid antibodies who are at risk for autoimmune thyroid disease: a hypothesis on the early phases of the endocrine autoimmune reaction. Journal of Clinical Endocrinology and Metabolism 98 2460-2468. (doi:10.1210/jc.2012-4122)

Beutler B, Greenwald D, Hulmes JD, Chang M, Pan YC, Mathison J, Ulevitch R \& Cerami A 1985 Identity of tumour necrosis factor and the macrophage-secreted factor cachectin. Nature 316 552-554. (doi:10.1038/316552a0)

Bhatti I, Peacock O, Lloyd G, Larvin M \& Hall RI 2010 Preoperative hematologic markers as independent predictors of prognosis in resected pancreatic ductal adenocarcinoma: neutrophil-lymphocyte versus platelet-lymphocyte ratio. American Journal of Surgery 200 197-203. (doi:10.1016/j.amjsurg.2009.08.041)

Bierie B \& Moses HL 2006 Tumour microenvironment: TGF $\beta$ : the molecular Jekyll and Hyde of cancer. Nature Reviews. Cancer 6 506-520. (doi:10.1038/nrc1926)

Bokarewa M, Nagaev I, Dahlberg L, Smith U \& Tarkowski A 2005 Resistin, an adipokine with potent proinflammatory properties. Journal of Immunology 174 5789-5795.

Brown TJ, Lioubin MN \& Marquardt H 1987 Purification and characterization of cytostatic lymphokines produced by activated human T lymphocytes. Synergistic antiproliferative activity of transforming growth factor $\beta 1$, interferon- $\gamma$, and oncostatin $M$ for human melanoma cells. Journal of Immunology 139 2977-2983.

Bruland O, Fluge O, Akslen LA, Eiken HG, Lillehaug JR, Varhaug JE \& Knappskog PM 2009 Inverse correlation between PDGFC expression and lymphocyte infiltration in human papillary thyroid carcinomas. BMC Cancer 9 425. (doi:10.1186/1471-2407-9-425)

Bufalo NE, Leite JL, Guilhen AC, Morari EC, Granja F, Assumpcao LV \& Ward LS 2006 Smoking and susceptibility to thyroid cancer: an inverse association with CYP1A1 allelic variants. Endocrine-Related Cancer 13 1185-1193. (doi:10.1677/ERC-06-0002)

Caillou B, Talbot M, Weyemi U, Pioche-Durieu C, Al Ghuzlan A, Bidart JM, Chouaib S, Schlumberger M \& Dupuy C 2011 Tumor-associated macrophages (TAMs) form an interconnected cellular supportive network in anaplastic thyroid carcinoma. PLOS ONE 6 e22567. (doi:10.1371/journal.pone.0022567)

Caturegli P, Hejazi M, Suzuki K, Dohan O, Carrasco N, Kohn LD \& Rose NR 2000 Hypothyroidism in transgenic mice expressing IFN- $\gamma$ in the thyroid. PNAS 97 1719-1724. (doi:10.1073/pnas.020522597)

Chan A, Hong DL, Atzberger A, Kollnberger S, Filer AD, Buckley CD, McMichael A, Enver T \& Bowness P 2007 CD56bright human NK cells differentiate into CD56dim cells: role of contact with peripheral fibroblasts. Journal of Immunology 179 89-94.

Chen BH, Song Y, Ding EL, Manson JE, Roberts CK, Rifai N, Buring JE, Gaziano JM \& Liu S 2010 Association of resistin promoter polymorphisms with plasma resistin levels and type 2 diabetes in women and men. International Journal of Molecular Epidemiology and Genetics 1 167-174.

Chen CJ, Sung WW, Su TC, Chen MK, Wu PR, Yeh KT, Ko JL \& Lee H 2013 High expression of interleukin 10 might predict poor prognosis in early stage oral squamous cell carcinoma patients. Clinica Chimica Acta $\mathbf{4 1 5}$ 25-30. (doi:10.1016/j.cca.2012.09.009)

Cheng SP, Chi CW, Tzen CY, Yang TL, Lee JJ, Liu TP \& Liu CL 2010 Clinicopathologic significance of leptin and leptin receptor expressions in papillary thyroid carcinoma. Surgery 147 847-853. (doi:10.1016) j.surg.2009.11.004)

Chew V, Chen J, Lee D, Loh E, Lee J, Lim KH, Weber A, Slankamenac K, Poon RT, Yang H et al. 2012 Chemokine-driven lymphocyte infiltration: an early intratumoural event determining long-term survival in resectable hepatocellular carcinoma. Gut 61 427-438. (doi:10.1136) gutjnl-2011-300509) 
Chiang SF, Hung HY, Tang R, Changchien CR, Chen JS, You YT, Chiang JM \& Lin JR 2012 Can neutrophil-to-lymphocyte ratio predict the survival of colorectal cancer patients who have received curative surgery electively? International Journal of Colorectal Disease 27 1347-1357. (doi:10.1007/s00384-012-1459-x)

Chow KC, Chiou SH, Ho SP, Tsai MH, Chen CL, Wang LS \& Chi KH 2003 The elevated serum interleukin- 6 correlates with the increased serum butyrate level in patients with nasopharyngeal carcinoma. Oncology Reports 10 813-819.

Clement JM \& McDermott DF 2009 The high-dose aldesleukin (IL-2) "select" trial: a trial designed to prospectively validate predictive models of response to high-dose IL-2 treatment in patients with metastatic renal cell carcinoma. Clinical Genitourinary Cancer 7 E7-E9. (doi:10.3816/CGC.2009.n.014)

Cooper MA, Fehniger TA \& Caligiuri MA 2001 $a$ The biology of human natural killer-cell subsets. Trends in Immunology 22 633-640. (doi:10.1016/S1471-4906(01)02060-9)

Cooper MA, Fehniger TA, Turner SC, Chen KS, Ghaheri BA, Ghayur T, Carson WE \& Caligiuri MA 2001b Human natural killer cells: a unique innate immunoregulatory role for the CD56(bright) subset. Blood 97 3146-3151. (doi:10.1182/blood.V97.10.3146)

Cowin AJ \& Bidey SP 1995 Porcine thyroid follicular cells in monolayer culture activate the iodide-responsive precursor form of transforming growth factor- $\beta 1$. Journal of Endocrinology 144 67-73. (doi:10.1677/ joe.0.1440067)

Cronan JJ 2008 Thyroid nodules: is it time to turn off the US machines? Radiology 247 602-604. (doi:10.1148/radiol.2473072233)

Cunha LL \& Ward LS 2011 Comments on "well-differentiated thyroid carcinoma with concomitant Hashimoto's thyroiditis present with less aggressive clinical stage and low recurrence". Endocrine Pathology 22 172-173. (doi:10.1007/s12022-011-9171-x)

Cunha LL \& Ward LS 2012 Concurrent lymphocytic thyroiditis is associated to less aggressive papillary thyroid carcinomas. European Archives of Oto-Rhino-Laryngology 269 699-700. (doi:10.1007/ s00405-011-1764-y)

Cunha LL, Tincani AJ, da Assumpcao LV, Soares FA, Vassallo J \& Ward LS 2011 Interleukin-10 but not interleukin-18 may be associated with the immune response against well-differentiated thyroid cancer. Clinics $\mathbf{6 6}$ 1203-1208. (doi:10.1590/S1807-59322011000700014)

Cunha LL, Morari EC, Guihen AC, Razolli D, Gerhard R, Nonogaki S, Soares FA, Vassallo J \& Ward LS 2012a Infiltration of a mixture of different immune cells may be related to molecular profile of differentiated thyroid cancer. Endocrine-Related Cancer 19 L31-L36. (doi:10.1530/ ERC-11-0285)

Cunha LL, Morari EC, Guihen AC, Razolli D, Gerhard R, Nonogaki S, Soares FA, Vassallo J \& Ward LS $2012 b$ Infiltration of a mixture of immune cells may be related to good prognosis in patients with differentiated thyroid carcinoma. Clinical Endocrinology 77 918-925. (doi:10.1111/ j.1365-2265.2012.04482.x)

Cunha LL, Marcello MA, Morari EC, Nonogaki S, Conte FF, Gerhard R, Soares FA, Vassallo J \& Ward LS 2013 Differentiated thyroid carcinomas may elude the immune system by B7H1 upregulation. Endocrine-Related Cancer 20 103-110. (doi:10.1530/ERC-12-0313)

Davis PJ 2008 Cytokines and growth factors and thyroid hormone. Current Opinion in Endocrinology, Diabetes, and Obesity 15428.

Davoine F, Sim A, Tang C, Fisher S, Ethier C, Puttagunta L, Wu Y, McGaw WT, Yu D, Cameron L et al. 2013 Eosinophils in human oral squamous carcinoma; role of prostaglandin D2. Journal of Inflammation 104. (doi:10.1186/1476-9255-10-4)

Dranoff G 2004 Cytokines in cancer pathogenesis and cancer therapy. Nature Reviews. Cancer 4 11-22. (doi:10.1038/nrc1252)

Dunn GP, Bruce AT, Ikeda H, Old LJ \& Schreiber RD 2002 Cancer immunoediting: from immunosurveillance to tumor escape. Nature Immunology 3 991-998. (doi:10.1038/ni1102-991)

Egler RA, Burlingame SM, Nuchtern JG \& Russell HV 2008 Interleukin-6 and soluble interleukin-6 receptor levels as markers of disease extent and prognosis in neuroblastoma. Clinical Cancer Research $\mathbf{1 4}$ 7028-7034. (doi:10.1158/1078-0432.CCR-07-5017)

Eke Koyuncu C, Turkmen Yildirmak S, Temizel M, Ozpacaci T, Gunel P, Cakmak M \& Ozbanazi YG 2013 Serum resistin and insulin-like growth factor-1 levels in patients with hypothyroidism and hyperthyroidism. Journal of Thyroid Research 2013 306750. (doi:10.1155/2013/306750)

El Demellawy D, Nasr A \& Alowami S 2008 Application of CD56, P63 and CK19 immunohistochemistry in the diagnosis of papillary carcinoma of the thyroid. Diagnostic Pathology 3 5. (doi:10.1186/1746-1596-3-5)

Eloy C, Santos J, Cameselle-Teijeiro J, Soares P \& Sobrinho-Simoes M 2012 TGF- $\beta /$ Smad pathway and BRAF mutation play different roles in circumscribed and infiltrative papillary thyroid carcinoma. Virchows Archiv 460 587-600. (doi:10.1007/s00428-012-1234-y)

Fabregat I, Fernando J, Mainez J \& Sancho P 2013 TGF- $\beta$ signaling in cancer treatment. Current Pharmaceutical Design [in press].

Fan J, Nishanian P, Breen EC, McDonald M \& Fahey JL 1998 Cytokine gene expression in normal human lymphocytes in response to stimulation. Clinical and Diagnostic Laboratory Immunology 5 335-340.

Fiumara A, Belfiore A, Russo G, Salomone E, Santonocito GM, Ippolito O, Vigneri R \& Gangemi P 1997 In situ evidence of neoplastic cell phagocytosis by macrophages in papillary thyroid cancer. Journal of Clinical Endocrinology and Metabolism 82 1615-1620. (doi:10.1210/ jc.82.5.1615)

French JD, Weber ZJ, Fretwell DL, Said S, Klopper JP \& Haugen BR 2010 Tumor-associated lymphocytes and increased FoxP3 + regulatory $\mathrm{T}$ cell frequency correlate with more aggressive papillary thyroid cancer. Journal of Clinical Endocrinology and Metabolism 95 2325-2333. (doi:10.1210/jc.2009-2564)

French JD, Kotnis GR, Said S, Raeburn CD, McIntyre RC Jr, Klopper JP \& Haugen BR 2012 Programmed death-1 + T cells and regulatory T cells are enriched in tumor-involved lymph nodes and associated with aggressive features in papillary thyroid cancer. Journal of Clinical Endocrinology and Metabolism 97 E934-E943. (doi:10.1210/jc.2011-3428)

Freud AG, Yokohama A, Becknell B, Lee MT, Mao HC, Ferketich AK \& Caligiuri MA 2006 Evidence for discrete stages of human natural killer cell differentiation in vivo. Journal of Experimental Medicine $\mathbf{2 0 3}$ 1033-1043. (doi:10.1084/jem.20052507)

Fridlender ZG, Sun J, Kim S, Kapoor V, Cheng G, Ling L, Worthen GS \& Albelda SM 2009 Polarization of tumor-associated neutrophil phenotype by TGF- $\beta$ : "N1" versus "N2" TAN. Cancer Cell 16 183-194. (doi:10.1016/j.ccr.2009.06.017)

Gillespie EF, Raychaudhuri N, Papageorgiou KI, Atkins SJ, Lu Y, Charara LK, Mester T, Smith TJ \& Douglas RS 2012 Interleukin-6 production in CD40-engaged fibrocytes in thyroid-associated ophthalmopathy: involvement of Akt and NF-kB. Investigative Ophthalmology \& Visual Science 53 7746-7753. (doi:10.1167/iovs.12-9861)

Gogali F, Paterakis G, Rassidakis GZ, Kaltsas G, Liakou CI, Gousis P, Neonakis E, Manoussakis MN \& Liapi C 2012 Phenotypical analysis of lymphocytes with suppressive and regulatory properties (Tregs) and NK cells in the papillary carcinoma of thyroid. Journal of Clinical Endocrinology and Metabolism 97 1474-1482. (doi:10.1210/jc.2011-1838)

Granja F, Morari J, Morari EC, Correa LA, Assumpcao LV \& Ward LS 2004a GST profiling may be useful in the screening for thyroid nodule malignancy. Cancer Letters 209 129-137. (doi:10.1016/j.canlet.2003. 12.013)

Granja F, Morari J, Morari EC, Correa LA, Assumpcao LV \& Ward LS 2004b Proline homozygosity in codon 72 of p53 is a factor of susceptibility for thyroid cancer. Cancer Letters 210 151-157. (doi:10.1016/j.canlet. 2004.01.016)

Guilhen AC, Bufalo NE, Morari EC, Leite JL, Assumpcao LV, Tincani AJ \& Ward LS 2009 Role of the N-acetyltransferase 2 detoxification system in thyroid cancer susceptibility. Clinical Cancer Research 15 406-412. (doi:10.1158/1078-0432.CCR-08-1835)

Gupta S, Patel A, Folstad A, Fenton C, Dinauer CA, Tuttle RM, Conran R \& Francis GL 2001 Infiltration of differentiated thyroid carcinoma by proliferating lymphocytes is associated with improved disease-free 
survival for children and young adults. Journal of Clinical Endocrinology and Metabolism 86 1346-1354. (doi:10.1210/jc.86.3.1346)

Halama N, Zoernig I \& Jaeger D 2010 Advanced malignant melanoma: immunologic and multimodal therapeutic strategies. Journal of Oncology 2010 689893. (doi:10.1155/2010/689893)

Hamanishi J, Mandai M, Iwasaki M, Okazaki T, Tanaka Y, Yamaguchi K, Higuchi T, Yagi H, Takakura K, Minato N et al. 2007 Programmed cell death 1 ligand 1 and tumor-infiltrating CD8 + T lymphocytes are prognostic factors of human ovarian cancer. PNAS $1043360-3365$. (doi:10.1073/pnas.0611533104)

Han JM, Kim TY, Jeon MJ, Yim JH, Kim WG, Song DE, Hong SJ, Bae SJ, Kim HK, Shin MH et al. 2013 Obesity is a risk factor for thyroid cancer in a large, ultrasonographically screened population. European Journal of Endocrinology 168 879-886. (doi:10.1530/EJE-13-0065)

Hanahan D \& Weinberg RA 2011 Hallmarks of cancer: the next generation. Cell 144 646-674. (doi:10.1016/j.cell.2011.02.013)

Hardy CL \& Balducci L 1985 Hemopoietic alterations of cancer. American Journal of the Medical Sciences 290 196-205. (doi:10.1097/00000441198511000-00004)

Herrmann G, Schumm-Draeger PM, Muller C, Atai E, Wenzel B, Fabian T, Usadel KH \& Hubner K 1994 T lymphocytes, CD68-positive cells and vascularisation in thyroid carcinomas. Journal of Cancer Research and Clinical Oncology 120 651-656. (doi:10.1007/BF01245376)

Hilly O, Koren R, Raz R, Rath-Wolfson L, Mizrachi A, Hamzany Y, Bachar G \& Shpitzer T 2013 The role of s100-positive dendritic cells in the prognosis of papillary thyroid carcinoma. American Journal of Clinical Pathology 139 87-92. (doi:10.1309/AJCPAKYDO56NKMYZ)

Hirano T, Taga T, Nakano N, Yasukawa K, Kashiwamura S, Shimizu K, Nakajima K, Pyun KH \& Kishimoto T 1985 Purification to homogeneity and characterization of human B-cell differentiation factor (BCDF or BSFp-2). PNAS 82 5490-5494. (doi:10.1073/pnas.82.16.5490)

Hirashima M, Higuchi S, Sakamoto K, Nishiyama T \& Okada H 1998 The ratio of neutrophils to lymphocytes and the phenotypes of neutrophils in patients with early gastric cancer. Journal of Cancer Research and Clinical Oncology 124 329-334. (doi:10.1007/s004320050178)

Hoon DS, Banez M, Okun E, Morton DL \& Irie RF 1991 Modulation of human melanoma cells by interleukin- 4 and in combination with $\gamma$-interferon or $\alpha$-tumor necrosis factor. Cancer Research $\mathbf{5 1}$ 2002-2008.

van Horssen R, ten Hagen TL \& Eggermont AM 2006 TNF- $\alpha$ in cancer treatment: molecular insights, antitumor effects, and clinical utility. Oncologist 11 397-408. (doi:10.1634/theoncologist.11-4-397)

Howard M, Farrar J, Hilfiker M, Johnson B, Takatsu K, Hamaoka T \& Paul WE 1982 Identification of a T cell-derived b cell growth factor distinct from interleukin 2. Journal of Experimental Medicine 155 914-923. (doi:10.1084/ jem.155.3.914)

Hsia CY, Huo TI, Chiang SY, Lu MF, Wu JC, Lui WY, Lee SD \& Wu CW 2006 Evaluation of interleukin-6, interleukin-10, and human hepatocyte growth factor as tumor markers for hepatocellular carcinoma. Journal of Gastroenterology and Hepatology 21 A187-A187.

Hsu DS, Kim MK, Balakumaran BS, Acharya CR, Anders CK, Clay T, Lyerly HK, Drake CG, Morse MA \& Febbo PG 2010 Immune signatures predict prognosis in localized cancer. Cancer Investigation 28 765-773. (doi:10.3109/07357900903095755)

Huang BY, Hseuh C, Chao TC, Lin KJ \& Lin JD 2011 Well-differentiated thyroid carcinoma with concomitant Hashimoto's thyroiditis present with less aggressive clinical stage and low recurrence. Endocrine Pathology 22 144-149. (doi:10.1007/s12022-011-9164-9)

Hurst SM, Wilkinson TS, McLoughlin RM, Jones S, Horiuchi S, Yamamoto N, Rose-John S, Fuller GM, Topley N \& Jones SA 2001 IL-6 and its soluble receptor orchestrate a temporal switch in the pattern of leukocyte recruitment seen during acute inflammation. Immunity 14 705-714. (doi:10.1016/S1074-7613(01)00151-0)

Ikeguchi M, Hatada T, Yamamoto M, Miyake T, Matsunaga T, Fukumoto Y, Yamada Y, Fukuda K, Saito H \& Tatebe S 2009 Serum interleukin-6 and -
10 levels in patients with gastric cancer. Gastric Cancer 12 95-100. (doi:10.1007/s10120-009-0509-8)

Kammoun-Krichen M, Bougacha-Elleuch N, Mnif M, Bougacha F, Charffedine I, Rebuffat S, Rebai A, Glasson E, Abid M, Ayadi F et al. 2012 IL-1 $\beta$ a potential factor for discriminating between thyroid carcinoma and atrophic thyroiditis. European Cytokine Network 23 101-106.

Kang JH, Yu BY \& Youn DS 2007 Relationship of serum adiponectin and resistin levels with breast cancer risk. Journal of Korean Medical Science 22 117-121. (doi:10.3346/jkms.2007.22.1.117)

Kaplan DH, Shankaran V, Dighe AS, Stockert E, Aguet M, Old LJ \& Schreiber RD 1998 Demonstration of an interferon $\gamma$-dependent tumor surveillance system in immunocompetent mice. PNAS 95 7556-7561. (doi:10.1073/ pnas.95.13.7556)

Karre K, Ljunggren HG, Piontek G \& Kiessling R 1986 Selective rejection of H-2-deficient lymphoma variants suggests alternative immune defence strategy. Nature 319 675-678. (doi:10.1038/319675a0)

Kim HJ, Lee YS, Won EH, Chang IH, Kim TH, Park ES, Kim MK, Kim W \& Myung SC 2011 Expression of resistin in the prostate and its stimulatory effect on prostate cancer cell proliferation. BJU International 108 E77-E83. (doi:10.1111/j.1464-410X.2010.09813.x)

Kimura ET, Kopp P, Zbaeren J, Asmis LM, Ruchti C, Maciel RM \& Studer H 1999 Expression of transforming growth factor $\beta(1), \beta(2)$, and $\beta(3)$ in multinodular goiters and differentiated thyroid carcinomas: a comparative study. Thyroid 9 119-125. (doi:10.1089/thy.1999.9.119)

Kimura H, Kimura M, Westra WH, Rose NR \& Caturegli P 2005 Increased thyroidal fat and goitrous hypothyroidism induced by interferon- $\gamma$. International Journal of Experimental Pathology 86 97-106. (doi:10.1111/ j.0959-9673.2005.00418.x)

Kimura HJ, Chen CY, Tzou SC, Rocchi R, Landek-Salgado MA, Suzuki K, Kimura M, Rose NR \& Caturegli P 2009 Immunoproteasome overexpression underlies the pathogenesis of thyroid oncocytes and primary hypothyroidism: studies in humans and mice. PLOS ONE 4 e7857. (doi:10.1371/journal.pone.0007857)

Kirkwood JM, Butterfield LH, Tarhini AA, Zarour H, Kalinski P \& Ferrone S 2012 Immunotherapy of cancer in 2012. CA: A Cancer Journal for Clinicians 62 309-335. (doi:10.3322/caac.20132)

Kloke O, Wandl U, Opalka B, Moritz T, Nagel-Hiemke M, Franz T, Becher R, Hirche H, Seeber S \& Niederle N 1992 A prospective randomized comparison of single-agent interferon (IFN)- $\alpha$ with the combination of IFN- $\alpha$ and low-dose IFN- $\gamma$ in chronic myelogenous leukaemia. European Journal of Haematology 48 93-98.

Kumada M, Kihara S, Ouchi N, Kobayashi H, Okamoto Y, Ohashi K, Maeda K, Nagaretani H, Kishida K, Maeda N et al. 2004 Adiponectin specifically increased tissue inhibitor of metalloproteinase-1 through interleukin-10 expression in human macrophages. Circulation 109 2046-2049. (doi:10.1161/01.CIR.0000127953.98131.ED)

Kurzrock R, Talpaz M, Kantarjian H, Walters R, Saks S, Trujillo JM \& Gutterman JU 1987 Therapy of chronic myelogenous leukemia with recombinant interferon- $\gamma$. Blood 70 943-947.

Kwon H \& Pessin JE 2013 Adipokines mediate inflammation and insulin resistance. Frontiers in Endocrinology 4 71. (doi:10.3389/ fendo.2013.00071)

Lanier LL 2008 Up on the tightrope: natural killer cell activation and inhibition. Nature Immunology 9 495-502. (doi:10.1038/ni1581)

Lanier LL, Le AM, Civin CI, Loken MR \& Phillips JH 1986 The relationship of CD16 (Leu-11) and Leu-19 (NKH-1) antigen expression on human peripheral blood NK cells and cytotoxic T lymphocytes. Journal of Immunology 136 4480-4486.

Larson SD, Jackson LN, Riall TS, Uchida T, Thomas RP, Qiu S \& Evers BM 2007 Increased incidence of well-differentiated thyroid cancer associated with Hashimoto thyroiditis and the role of the PI3k/Akt pathway. Journal of the American College of Surgeons 204 764-773 (discussion 773-775). (doi:10.1016/j.jamcollsurg.2006.12.037)

Lee DH 2012 Morphologic evidence of anti-tumor specificity of T cells activated by dendritic cells derived from peripheral blood mononuclear 
cells of thyroid cancer patients. Korean Journal of Physiology \& Pharmacology 16 243-247. (doi:10.4196/kjpp.2012.16.4.243)

Lewis JD, Reilly BD \& Bright RK 2003 Tumor-associated antigens: from discovery to immunity. International Reviews of Immunology 22 81-112. (doi:10.1080/08830180305221)

Lewis AM, Varghese S, Xu H \& Alexander HR 2006 Interleukin-1 and cancer progression: the emerging role of interleukin-1 receptor antagonist as a novel therapeutic agent in cancer treatment. Journal of Translational Medicine 4 48. (doi:10.1186/1479-5876-4-48)

Li S, Shin HJ, Ding EL \& van Dam RM 2009 Adiponectin levels and risk of type 2 diabetes: a systematic review and meta-analysis. Journal of the American Medical Association 302 179-188. (doi:10.1001/jama.2009.976)

Liang X, De Vera ME, Buchser WJ, Romo de Vivar Chavez A, Loughran P, Beer Stolz D, Basse P, Wang T, Van Houten B, Zeh HJ III et al. 2012 Inhibiting systemic autophagy during interleukin 2 immunotherapy promotes long-term tumor regression. Cancer Research 72 2791-2801. (doi:10.1158/0008-5472.CAN-12-0320)

Liapi C, Gogali F, Paterakis G, Rassidakis GZ \& Liakou CI 2013 CD3CD16-CD56 bright immunoregulatory NK cells are increased in the tumor microenvironment and inversely correlate with advanced stages in patients with papillary thyroid cancer. Thyroid (epub).

Lin Q, Huang MS, Hu B, Dong M, Wen JY \& Wu XY 2007 Serum levels of macrophage migration inhibitory factor and interleukin-8 in hepatocellular carcinoma patients: their correlations with tumor progression and prognosis. Zhonghua Gan Zang Bing Za Zhi 15 463-464.

Liotti F, Visciano C \& Melillo RM 2012 Inflammation in thyroid oncogenesis. American Journal of Cancer Research 2 286-297.

Lippitz BE 2013 Cytokine patterns in patients with cancer: a systematic review. Lancet Oncology 14 e218-e228. (doi:10.1016/S14702045(12)70582-X)

Liu CL, Lee JJ, Liu TP, Chang YC, Hsu YC \& Cheng SP 2013 Blood neutrophil-to-lymphocyte ratio correlates with tumor size in patients with differentiated thyroid cancer. Journal of Surgical Oncology 107 493-497. (doi:10.1002/jso.23270)

Ljunggren HG 2008 Cancer immunosurveillance: NKG2D breaks cover. Immunity 28 492-494. (doi:10.1016/j.immuni.2008.03.007)

Mantovani A, Sozzani S, Locati M, Allavena P \& Sica A 2002 Macrophage polarization: tumor-associated macrophages as a paradigm for polarized M2 mononuclear phagocytes. Trends in Immunology 23 549-555. (doi:10.1016/S1471-4906(02)02302-5)

Marcello MA, Sampaio AC, Geloneze B, Vasques AC, Assumpcao LV \& Ward LS 2012 Obesity and excess protein and carbohydrate consumption are risk factors for thyroid cancer. Nutrition and Cancer 64 1190-1195. (doi:10.1080/01635581.2012.721154)

Matsubayashi S, Kawai K, Matsumoto Y, Mukuta T, Morita T, Hirai K, Matsuzuka F, Kakudoh K, Kuma K \& Tamai H 1995 The correlation between papillary thyroid carcinoma and lymphocytic infiltration in the thyroid gland. Journal of Clinical Endocrinology and Metabolism $\mathbf{8 0}$ 3421-3424. (doi:10.1210/jc.80.12.3421)

Mazzaferri EL 2006 Managing small thyroid cancers. Journal of the American Medical Association 295 2179-2182. (doi:10.1001/jama.295.18.2179)

Medzhitov R 2010 Inflammation 2010: new adventures of an old flame. Cell 140 771-776. (doi:10.1016/j.cell.2010.03.006)

Melillo RM, Guarino V, Avilla E, Galdiero MR, Liotti F, Prevete N, Rossi FW, Basolo F, Ugolini C, de Paulis A et al. 2010 Mast cells have a protumorigenic role in human thyroid cancer. Oncogene 29 6203-6215. (doi:10.1038/onc.2010.348)

Miller CHT, Maher SG \& Young HA 2009 Clinical use of interferon- $\gamma$. Annals of the New York Academy of Sciences 1182 69-79. (doi:10.1111/j. 1749-6632.2009.05069.x)

Mitsiades N, Pazaitou-Panayiotou K, Aronis KN, Moon HS, Chamberland JP, Liu X, Diakopoulos KN, Kyttaris V, Panagiotou V, Mylvaganam G et al. 2011 Circulating adiponectin is inversely associated with risk of thyroid cancer: in vivo and in vitro studies. Journal of Clinical Endocrinology and Metabolism 96 E2023-E2028. (doi:10.1210/jc.2010-1908)
Modi J, Patel A, Terrell R, Tuttle RM \& Francis GL 2003 Papillary thyroid carcinomas from young adults and children contain a mixture of lymphocytes. Journal of Clinical Endocrinology and Metabolism $\mathbf{8 8}$ 4418-4425. (doi:10.1210/jc.2003-030342)

Morari EC, Silva JR, Guilhen AC, Cunha LL, Marcello MA, Soares FA, Vassallo J \& Ward LS 2010 Muc-1 expression may help characterize thyroid nodules but does not predict patients' outcome. Endocrine Pathology 21 242-249. (doi:10.1007/s12022-010-9137-4)

Morosini PP, Taccaliti A, Arnaldi G, Simonella G, Petrelli MD, Mancini V, Montironi R, Scarpelli M, Diamanti L \& Mantero F 1996 Enhanced expression of transforming growth factor $\beta 1$ in rat thyroid hyperplasia is thyrotropin induced and time dependent. European Journal of Endocrinology 134 373-378. (doi:10.1530/eje.0.1340373)

Murphy K 2011 Innate Immunity. In K Murphy (Ed.) Janeway's Immunobiology, edn 8, 37-73. New York: Garland Science.

Muzza M, Degl'Innocenti D, Colombo C, Perrino M, Ravasi E, Rossi S, Cirello V, Beck-Peccoz P, Borrello MG \& Fugazzola L 2010 The tight relationship between papillary thyroid cancer, autoimmunity and inflammation: clinical and molecular studies. Clinical Endocrinology 72 702-708. (doi:10.1111/j.1365-2265.2009.03699.x)

Nagumo A, Yasuda K, Numazaki H, Azuma H, Tanabe Y, Kikuchi S, Harata S \& Tohyama H 2005 Effects of separate application of three growth factors (TGF- $\beta 1, \mathrm{EGF}$, and PDGF-BB) on mechanical properties of the in situ frozen-thawed anterior cruciate ligament. Clinical Biomechanics 20 283-290. (doi:10.1016/j.clinbiomech.2004.11.004)

Niitsu N, Okamoto M, Nakamine H, Yoshino T, Tamaru J, Nakamura S, Higashihara M \& Hirano M 2002 Simultaneous elevation of the serum concentrations of vascular endothelial growth factor and interleukin-6 as independent predictors of prognosis in aggressive non-Hodgkin's lymphoma. European Journal of Haematology 68 91-100. (doi:10.1034/ j.1600-0609.2002.01609.x)

Nikiforov YE 2010 Is ionizing radiation responsible for the increasing incidence of thyroid cancer? Cancer 116 1626-1628. (doi:10.1002/cncr.24889)

Nikiteas NI, Tzanakis N, Gazouli M, Rallis G, Daniilidis K, Theodoropoulos G, Kostakis A \& Peros G 2005 Serum IL-6, TNF $\alpha$ and CRP levels in Greek colorectal cancer patients: prognostic implications. World Journal of Gastroenterology 11 1639-1643.

Onishi T, Ohishi Y, Imagawa K, Ohmoto Y \& Murata K 1999 An assessment of the immunological environment based on intratumoral cytokine production in renal cell carcinoma. BJU International 83 488-492. (doi:10.1046/j.1464-410x.1999.00925.x)

Ouyang Q, Baerlocher G, Vulto I \& Lansdorp PM 2007 Telomere length in human natural killer cell subsets. Annals of the New York Academy of Sciences 1106 240-252. (doi:10.1196/annals.1392.001)

Park SW, Kim MK, Kwon KH \& Kim J 2012 Association between a promoter polymorphism (rs2192752, - 1028A/C) of interleukin 1 receptor, type I (IL1R1) and location of papillary thyroid carcinoma in a Korean population. International Journal of Immunogenetics 39 501-507. (doi:10.1111/j.1744-313X.2012.01125.x)

Perrier S, Caldefie-Chezet F \& Vasson MP 2009 IL-1 family in breast cancer: potential interplay with leptin and other adipocytokines. FEBS Letters 583 259-265. (doi:10.1016/j.febslet.2008.12.030)

Popova EV, Popova NP, Aliab'eva IV \& Gatiatulina ER 2012 Interleukin-6 in endemic goiter patients in the south Ural region. Gigiena i Sanitariia 9-10.

Poschke I, Mougiakakos D \& Kiessling R 2011 Camouflage and sabotage: tumor escape from the immune system. Cancer Immunology, Immunotherapy 60 1161-1171. (doi:10.1007/s00262-011-1012-8)

Proietti A, Ugolini C, Melillo RM, Crisman G, Elisei R, Santoro M, Minuto M, Vitti P, Miccoli P \& Basolo F 2011 Higher intratumoral expression of CD1a, tryptase, and CD68 in a follicular variant of papillary thyroid carcinoma compared to adenomas: correlation with clinical and pathological parameters. Thyroid 21 1209-1215. (doi:10.1089/thy.2011.0059)

Pusztaszeri MP, Sadow PM \& Faquin WC 2013 Association of CD1a-positive dendritic cells with papillary thyroid carcinoma in thyroid fine-needle aspirations: a cytologic and immunocytochemical evaluation. Cancer Cytopathology 121 206-213. (doi:10.1002/cncy.21239) http://erc.endocrinology-journals.org DOI: 10.1530/ERC-13-0431 (c) 2014 Society for Endocrinology Printed in Great Britain 
Rebuffat SA, Kammoun-Krichen M, Charfeddine I, Ayadi H, Bougacha-Elleuch N \& Peraldi-Roux S 2013 IL-1 $\beta$ and TSH disturb thyroid epithelium integrity in autoimmune thyroid diseases. Immunobiology 218 285-291. (doi:10.1016/j.imbio.2012.05.016)

Ribatti D, Vacca A, Nico B, Crivellato E, Roncali L \& Dammacco F 2001 The role of mast cells in tumour angiogenesis. British Journal of Haematology 115 514-521. (doi:10.1046/j.1365-2141.2001.03202.x)

Roberts AB \& Wakefield LM 2003 The two faces of transforming growth factor $\beta$ in carcinogenesis. PNAS 100 8621-8623. (doi:10.1073/pnas. 1633291100)

Rotondi M, Coperchini F, Pignatti P, Sideri R, Groppelli G, Leporati P, La Manna L, Magri F, Mariotti S \& Chiovato L 2013 Interferon- $\gamma$ and tumor necrosis factor- $\alpha$ sustain secretion of specific CXC chemokines in human thyrocytes: a first step toward a differentiation between autoimmune and tumor-related inflammation? Journal of Clinical Endocrinology and Metabolism 98 308-313. (doi:10.1210/jc.2012-2555)

Ruco LP, Ranalli T, Marzullo A, Bianco P, Prat M, Comoglio PM \& Baroni CD 1996 Expression of Met protein in thyroid tumours. Journal of Pathology 180 266-270. (doi:10.1002/(SICI)1096-9896(199611)180:3<266::AIDPATH658 > 3.0.CO;2-Q)

Ryder M, Ghossein RA, Ricarte-Filho JC, Knauf JA \& Fagin JA 2008 Increased density of tumor-associated macrophages is associated with decreased survival in advanced thyroid cancer. Endocrine-Related Cancer 15 1069-1074. (doi:10.1677/ERC-08-0036)

Ryder M, Gild M, Hohl TM, Pamer E, Knauf J, Ghossein R, Joyce JA \& Fagin JA 2013 Genetic and pharmacological targeting of CSF-1/CSF-1R inhibits tumor-associated macrophages and impairs BRAF-induced thyroid cancer progression. PLoS ONE 8 e54302. (doi:10.1371/journal.pone. 0054302)

Sanchez-Capelo A 2005 Dual role for TGF- $\beta 1$ in apoptosis. Cytokine \& Growth Factor Reviews 16 15-34. (doi:10.1016/j.cytogfr.2004.11.002)

Sato T, McCue P, Masuoka K, Salwen S, Lattime EC, Mastrangelo MJ \& Berd D 1996 Interleukin 10 production by human melanoma. Clinical Cancer Research 2 1383-1390.

Scarpino S, Stoppacciaro A, Colarossi C, Cancellario F, Marzullo A, Marchesi M, Biffoni M, Comoglio PM, Prat M \& Ruco LP 1999 Hepatocyte growth factor (HGF) stimulates tumour invasiveness in papillary carcinoma of the thyroid. Journal of Pathology 189 570-575. (doi:10.1002/(SICI)1096-9896(199912)189:4<570::AID-PATH470>3. $0 . \mathrm{CO} ; 2-3)$

Schott M 2006 Immunosurveillance by dendritic cells: potential implication for immunotherapy of endocrine cancers. Endocrine-Related Cancer 13 779-795. (doi:10.1677/erc.1.01133)

Schroder S, Schwarz W, Rehpenning W, Loning T \& Bocker W 1988 Dendritic/Langerhans cells and prognosis in patients with papillary thyroid carcinomas. Immunocytochemical study of 106 thyroid neoplasms correlated to follow-up data. American Journal of Clinical Pathology 89 295-300.

Seretis C, Gourgiotis S, Gemenetzis G, Seretis F, Lagoudianakis E \& Dimitrakopoulos G 2013 The significance of neutrophil/lymphocyte ratio as a possible marker of underlying papillary microcarcinomas in thyroidal goiters: a pilot study. American Journal of Surgery 205 691-696. (doi:10.1016/j.amjsurg.2012.08.006)

Sipos JA \& Mazzaferri EL 2010 Thyroid cancer epidemiology and prognostic variables. Clinical Oncology 22 395-404. (doi:10.1016/j.clon. 2010.05.004)

Smyth MJ, Thia KY, Street SE, Cretney E, Trapani JA, Taniguchi M, Kawano T, Pelikan SB, Crowe NY \& Godfrey DI 2000 Differential tumor surveillance by natural killer (NK) and NKT cells. Journal of Experimental Medicine 191 661-668. (doi:10.1084/jem.191.4.661)

Stassi G, Todaro M, Zerilli M, Ricci-Vitiani L, Di Liberto D, Patti M, Florena A, Di Gaudio F, Di Gesu G \& De Maria R 2003 Thyroid cancer resistance to chemotherapeutic drugs via autocrine production of interleukin- 4 and interleukin-10. Cancer Research 63 6784-6790.
Steinman RM 1991 The dendritic cell system and its role in immunogenicity. Annual Review of Immunology 9 271-296. (doi:10.1146/ annurev.iy.09.040191.001415)

Steppan CM, Wang J, Whiteman EL, Birnbaum MJ \& Lazar MA 2005 Activation of SOCS-3 by resistin. Molecular and Cellular Biology 25 1569-1575. (doi:10.1128/MCB.25.4.1569-1575.2005)

Su X, Ye J, Hsueh EC, Zhang Y, Hoft DF \& Peng G 2010 Tumor microenvironments direct the recruitment and expansion of human Th17 cells. Journal of Immunology 184 1630-1641. (doi:10.4049/ jimmunol.0902813)

Sun CA, Wu MH, Chu CH, Chou YC, Hsu GC, Yang T, Chou WY, Yu CP \& $\mathrm{Yu}$ JC 2010 Adipocytokine resistin and breast cancer risk. Breast Cancer Research and Treatment 123 869-876. (doi:10.1007/s10549-010-0792-4)

Suzuki S, Mita S, Kamohara H, Sakamoto K, Ishiko T \& Ogawa M 2001 IL-6 and IFN- $\gamma$ regulation of IL-10 production by human colon carcinoma cells. International Journal of Oncology 18 581-586.

Suzuki K, Kachala SS, Kadota K, Shen R, Mo Q, Beer DG, Rusch VW, Travis WD \& Adusumilli PS 2011 Prognostic immune markers in non-small cell lung cancer. Clinical Cancer Research 17 5247-5256. (doi:10.1158/10780432.CCR-10-2805)

Takemura Y, Ouchi N, Shibata R, Aprahamian T, Kirber MT, Summer RS, Kihara S \& Walsh K 2007 Adiponectin modulates inflammatory reactions via calreticulin receptor-dependent clearance of early apoptotic bodies. Journal of Clinical Investigation 117 375-386. (doi:10.1172/JCI29709)

Tas F, Oguz H, Argon A, Duranyildiz D, Camlica H, Yasasever V \& Topuz E 2005 The value of serum levels of IL-6, TNF- $\alpha$, and erythropoietin in metastatic malignant melanoma: serum IL-6 level is a valuable prognostic factor at least as serum LDH in advanced melanoma. Medical Oncology 22 241-246. (doi:10.1385/MO:22:3:241)

Thompson RH, Kuntz SM, Leibovich BC, Dong H, Lohse CM, Webster WS, Sengupta S, Frank I, Parker AS, Zincke H et al. 2006 Tumor B7-H1 is associated with poor prognosis in renal cell carcinoma patients with long-term follow-up. Cancer Research 66 3381-3385. (doi:10.1158/ 0008-5472.CAN-05-4303)

Todaro M, Zerilli M, Ricci-Vitiani L, Bini M, Perez Alea M, Maria Florena A, Miceli L, Condorelli G, Bonventre S, Di Gesu G et al. 2006 Autocrine production of interleukin-4 and interleukin-10 is required for survival and growth of thyroid cancer cells. Cancer Research 66 1491-1499. (doi:10.1158/0008-5472.CAN-05-2514)

Ugolini C, Basolo F, Proietti A, Vitti P, Elisei R, Miccoli P \& Toniolo A 2007 Lymphocyte and immature dendritic cell infiltrates in differentiated, poorly differentiated, and undifferentiated thyroid carcinoma. Thyroid 17 389-393. (doi:10.1089/thy.2006.0306)

Vella V, Mineo R, Frasca F, Mazzon E, Pandini G, Vigneri R \& Belfiore A 2004 Interleukin-4 stimulates papillary thyroid cancer cell survival: implications in patients with thyroid cancer and concomitant Graves' disease. Journal of Clinical Endocrinology and Metabolism 89 2880-2889. (doi:10.1210/jc.2003-031639)

Vendramini-Costa DB \& Carvalho JE 2012 Molecular link mechanisms between inflammation and cancer. Current Pharmaceutical Design 18 3831-3852. (doi:10.2174/138161212802083707)

Villagelin DG, Santos RB \& Romaldini JH 2011 Is diffuse and peritumoral lymphocyte infiltration in papillary thyroid cancer a marker of good prognosis? Journal of Endocrinological Investigation 34 e403-e408.

de Visser KE, Eichten A \& Coussens LM 2006 Paradoxical roles of the immune system during cancer development. Nature Reviews. Cancer 6 24-37. (doi:10.1038/nrc1782)

Vivier E, Raulet DH, Moretta A, Caligiuri MA, Zitvogel L, Lanier LL, Yokoyama WM \& Ugolini S 2011 Innate or adaptive immunity? The example of natural killer cells Science 331 44-49. (doi:10.1126/science. 1198687)

Wajant H 2009 The role of TNF in cancer. Results and Problems in Cell Differentiation 49 1-15. 
Waldmann TA 2006 The biology of interleukin-2 and interleukin-15: implications for cancer therapy and vaccine design. Nature Reviews. Immunology 6 595-601. (doi:10.1038/nri1901)

Walsh SR, Cook EJ, Goulder F, Justin TA \& Keeling NJ 2005 Neutrophillymphocyte ratio as a prognostic factor in colorectal cancer. Journal of Surgical Oncology 91 181-184. (doi:10.1002/jso.20329)

Wartofsky L 2010 Increasing world incidence of thyroid cancer: increased detection or higher radiation exposure? Hormones 9 103-108.

Xu L, Morari EC, Wei Q, Sturgis EM \& Ward LS 2012 Functional variations in the ATM gene and susceptibility to differentiated thyroid carcinoma. Journal of Clinical Endocrinology and Metabolism 97 1913-1921. (doi:10.1210/jc.2011-3299)

Yadav NS, Singh P, Bansode FW \& Singh RK 2012 Role of cytokine signalling in head and neck cancers. International Journal of Basic and Applied Medical Sciences 26.

Yano Y, Shibuya H, Kitagawa W, Nagahama M, Sugino K, Ito K \& Ito K 2007 Recent outcome of Graves' disease patients with papillary thyroid cancer. European Journal of Endocrinology 157 325-329. (doi:10.1530/ EJE-07-0136)

Yokota T, Oritani K, Takahashi I, Ishikawa J, Matsuyama A, Ouchi N, Kihara S, Funahashi T, Tenner AJ, Tomiyama Y et al. 2000 Adiponectin, a new member of the family of soluble defense collagens, negatively regulates the growth of myelomonocytic progenitors and the functions of macrophages. Blood 96 1723-1732.

Yu H, Huang X, Liu X, Jin H, Zhang G, Zhang Q \& Yu J 2013 Regulatory $\mathrm{T}$ cells and plasmacytoid dendritic cells contribute to the immune escape of papillary thyroid cancer coexisting with multinodular non-toxic goiter. Endocrine 44 172-181. (doi:10.1007/s12020012-9853-2)

Yuasa R, Eggo MC, Meinkoth J, Dillmann WH \& Burrow GN 1992 Iodide induces transforming growth factor $\beta 1$ (TGF- $\beta 1$ ) mRNA in sheep thyroid cells. Thyroid 2 141-145. (doi:10.1089/thy. 1992.2.141)

Zahorec R 2001 Ratio of neutrophil to lymphocyte counts - rapid and simple parameter of systemic inflammation and stress in critically ill. Bratislavské Lekárske Listy 102 5-14.

Zanetti A, Stoppacciaro A, Marzullo A, Ciabatta M, Fazioli F, Prat M, Comoglio PM, Baroni CD \& Ruco LP 1998 Expression of Met protein and urokinase-type plasminogen activator receptor (uPA-R) in papillary carcinoma of the thyroid. Journal of Pathology 186 287-291. (doi:10.1002/ (SICI)1096-9896(199811)186:3 < 287::AID-PATH175 > 3.0.CO;2-X)

Zhang YJ, Zhao W, Zhu MY, Tang SS \& Zhang H 2013 Thyroid-stimulating hormone induces the secretion of tumor necrosis factor- $\alpha$ from 3T3-L1 adipocytes via a protein kinase A-dependent Pathway. Experimental and Clinical Endocrinology \& Diabetes 121 488-493.

Zhao ZG, Guo XG, Ba CX, Wang W, Yang YY, Wang J \& Cao HY 2012 Overweight, obesity and thyroid cancer risk: a meta-analysis of cohort studies. Journal of International Medical Research 40 2041-2050. (doi:10.1177/030006051204000601)

Zhou G \& Levitsky HI 2007 Natural regulatory T cells and de novo-induced regulatory $\mathrm{T}$ cells contribute independently to tumor-specific tolerance. Journal of Immunology 178 2155-2162.

Received in final form 15 November 2013

Accepted 3 December 2013

Made available online as an Accepted Preprint

3 December 2013
(C) 2014 Society for Endocrinology Printed in Great Britain
Published by Bioscientifica Ltd. 